\title{
Dünyada ve Türkiye'de Tıbbi -Aromatik Bitkilerin Üretimi ve Ticareti
}

\author{
Mükremin TEMEL ${ }^{1}$ (D) A. Bircan TINMAZ1 ${ }^{1}$ Mustafa ÖZTÜRK ${ }^{1}$ (D) Orhan GÜNDÜZ ${ }^{2}$ (D) \\ ${ }^{1}$ Atatürk Bahçe Kültürleri Merkez Araştırma Enstitüsü, Yalova, ${ }^{2}$ Turgut Özal Üniversitesi, Battalgazi Meslek Yüksek Okulu, Malatya \\ $\bowtie$ : mukremintemel@gmail.com
}

\section{ÖZET}

Çalışmada, tıbbi ve aromatik bitkilerinin 2000'li yıllardan günümüze kadar üretimi, dünya ticareti ve değişimi hakkında detaylı bilgiler vermek amaçlanmıştır. Araştırma verileri FAO, ITC kayıtlarından tarama, süzme ve gruplandırma usulüyle elde edilmiş ve çizelgelerde özetlenmiştir. Bulgulara göre muhtelif sayıda tıbbi ve aromatik bitkinin yaklaşık 36 milyon hektar alanda tarımı yapılmakta, üretim miktarı yönünden kahve, kakao, çay, kırmızı biber ilk sıralarda yer almaktadır. Kakao, çay, nane üretim alanları 2016 yılına kadar yaklaşık \%50 artmıştır. Buna karşın keçiboynuzu, karabuğday, kenevir, şerbetçiotu üretim alanlarında azalışlar meydana gelmiştir. Tıbbi ve aromatik bitkilerin dış ticaretinde birçok bitki yer almaktadır. Dünya tıbbi ve aromatik bitkiler ticaretinin büyüklüğü 2000 yılında 50 milyar dolarken 2016 yılında 180 milyar dolara yükselmiştir. Kahve, kakao, çay ticaretin ilk sıralarında yer almaktadır. Brezilya en önemli kahve ihracatçısı iken ABD ise en önemli ithalatçı konumundadır. Uçucu yağlar ihracatında, Çin ilk sırada yer alırken ithalatta ilk sırayı ABD almaktadır. Ticaret hacmi \%300 artışla en fazla kahve, çay ve mate grubunda gerçekleşmiştir. Türkiye ise dünya ticaretinde orta siralarda yer almaktadır. Araştırma bulgularına göre Türkiye'de yaklaşı 20 çeşit tıbbi ve aromatik bitkinin 1,3 milyon dekar alanda tarımı yapılmaktadır. 2000 'den 2015 yılına üretim alanları yaklaşık \%40 artmıştır. Tıbbi ve aromatik bitkileri dış ticareti, 2015 yılında, 280 milyon dolar ihracat ve 254 milyon dolar ithalat şeklinde gerçekleşmiştir. İhracatta kekik \%25'lik payla ilk sırada yer almaktadır. İthalatın \%61'ini kahve oluşturmaktadır. İhracatta en önemli uçucu yağlar gül, kekik, stearopten, portakaldır. İthalatta önemli uçucu yağlar nane, portakal, limon, diğer turunçgiller, lavantadır. Sonuç olarak, dünya tıbbi ve aromatik bitkilerinin üretimi artmakla birlikte ticareti daha hızlı artmaktadir.

\section{Makale Tarihçesi}

Geliş : 21.10.2018

Kabul : 27.12.2018

Anahtar Kelimeler

Tıbbi ve Aromatik Bitkiler,

Üretim,

Ithalat,

Ihracat,

Türkiye,

Dünya

\section{Derleme Makalesi}

\section{Production and Trade of Medicinal and Aromatic Plants in the World and Turkey}

\section{ABSTRACT}

In this study, it was aimed to give information about production, foreign trade and changes of medicinal and aromatic plants in Turkey from 2000 to the present. Research data was obtained from FAO and ITC records by screening, filtering and grouping and was subjected to descriptive statistics. According to the findings, a total of 36 million hectares of medicinal and aromatic plants are cultivated and coffee, cocoa, tea and red pepper were at the top of the list. Cocoa, tea and mint production areas increased about $50 \%$ by 2016 . On the other hand, decreases have been observed in the production areas of carob, buckwheat, hemp and hops. Dozens of medicinal and aromatic plants were sujected to the Foreign trade. While the size of world medicinal and aromatic plants trade was 50 billion dollars in 2000, it increased to 180 billion dollars in 2016. Coffee, cocoa and tea are at the top of the trade. While Brazil is the most important coffee exporter, the USA is the most important importer. In the export of essential oils, China is in the first place, while the USA is the first in importation. Trade

\section{Article History}

Received : 21.10.2018

Accepted : 27.12.2018

Keywords
Medicinal and Aromatic Plants,
Production,
Export,
Import,
Turkey,
World

\section{Review Article}


volume increased by $300 \%$ mostly in coffee, tea and mate groups. Turkey is ranked in the middle in world trade. In the study, all medicinal and aromatic plants were examined for secondary benefits. According to findings, about 20 million medicinal and aromatic plants are cultivated in about 1.3 million decares of land. From 2000 to 2015, production areas increased by about $40 \%$. Foreign trade of medicinal and aromatic plants were realized in 2015 with export of 280 million dollars and import of 254 million dollars. Thyme is in the first place with $25 \%$ share in exports. Coffee constitutes $61 \%$ of the import. The most important essential oils in export were rose, thyme, stearopten and orange. Import essential essential oils were mint, orange, lemon, other citrus fruits, lavender. As a result, the production of medicinal and aromatic plants in the world is increasing but the trade is increasing even faster.

To cite: Temel M, Tınmaz AB, Öztürk M, Gündüz O 2018. Dünyada ve Türkiye'de Tibbi-Aromatik Bitkilerin Üretimi ve Ticareti. KSÜ Tar Doğa Derg 21(Özel Sayl) : 198-214, DOI : 10.18016/ ksutarimdoga.vi.473036

\section{GİRIŞ}

Tıbbi bitkilerin tanımını tam olarak yapmak mümkün değildir. Günümüzde "tıbbi" ve "aromatik" bitkiler terimi genellikle birlikte kullanılmaktadır. Tıbbi ve aromatik bitkiler, hastalıkları önlemek, sağlığ sürdürmek veya hastalıkları iyileştirmek için ilaç olarak kullanılan bitkilerdir. Tibbi bitkiler, beslenme, kozmetik, vücut bakımı, tütsü veya dini törenler gibi alanlarda yer alırken, aromatik bitkiler ise, güzel koku ve tat vermeleri için kullanılmaktadır (Anonim, 2005; Arslan ve ark., 2015).

Tıbbi ve aromatik bitkiler hastalıkların önlenmesi, sağlığın sürdürülmesi ve hastalıkların iyileştirilmesi için ilaç olarak geleneksel ve modern tıpta kullanılmaktadır. Aynı zamanda besin takviyeleri, bitkisel çay, tat, çeşni olarak beslenmede faydalanılmaktadır. Parfüm, vücut bakım ürünleri olarak parfümeri ve kozmetikte kullanılmasının yanı sıra, parlatıcı hatta böcek ilaçları olarak sanayinin farklı kollarında geniş bir kullanım alanı bulmaktadır. $\mathrm{Bu}$ bitkilerin drog denilen kurutulmuş, belirli ölçüde hazırlanmış bu bitki kısımlarından (kök, kök-sap, yumru, gövde veya odunsu yapı, kabuk, yaprak, çiçek, meyve, tohum ve herba) yararlanılmaktadır (Anonim, 2012).

Bitkilerin iyileştirici etkilerinin bulunduğu inancı çok eskilere kadar gitmektedir. Tibbi ve aromatik bitkiler hakkında en eski kitabın Çin hükümdarı Shin-Nong tarafindan M.Ö. 3700 yıllarında yazıldığ belirtilmektedir. Hükümdar yazdığı kitapta 200'den fazla bitkiden bahsetmektedir. Eski devirlere ait mezarlarda bulunan yazı ve şekiller bize Mısırlıların Çinlilerle aynı zaman diliminde bitkisel droglardan faydalandıklarını ve bunların ticaretini yaptıklarını göstermektedir (Ceylan, 1995).

Dünya Sağlık Örgütü (WHO) verilerine göre yaklaşık 20.000 bitki tıbbi amaçlarla kullanılmaktadır. Dünyada bitkisel droglar için başlıca ticaret merkezleri Çin, Almanya, ABD, Fransa, İtalya,
Japonya, İspanya, İngiltere ve Hong Kong'dur (Faydaoğlu ve Sucuoğlu, 2011). Dünyada toplam 422.000 bitki tür sayısı yer alırken bunlardan 52.885'i tıbbi ve aromatiktir. En fazla tıbbi ve aromatik bitki türü sayısı 4.941 ile Çin'de bulunurken 3.000 ile Hindistan, 2.564 ile ABD, 1.800 ile Vietnam, 1200 ile Malezya ve 1.000 ile Endonezya takip etmektedir. Türkiye'nin ise tıbbi ve aromatik bitki tür sayısı 500'dür (FAO, 2015). Türkiye florası, belirlenen 10.000'in üzerinde bitki çeşidi ile Avrupa'nın tamamının sahip olduğu bitki sayısına (yaklaşık 12.000) yakın olup, büyük bir çeşitlilik ve zenginlik göstermektedir. Floranın 1/3'ünü aromatik bitkiler oluşturmakta olup, 3.000 kadar bitki de endemiktir. Aktarlarda satılan bitki sayısı 300 civarında olup 70100 kadar bitkinin ihracatı yapılmaktadır (Başer, 1997). Türkiye, coğrafi konumu, iklim ve bitki çeşitliliği, tarımsal potansiyeli, geniş yüzölçümü sayesinde tıbbi ve aromatik bitkiler ticaretinde önde gelen ülkelerden biridir (Bayram ve ark., 2010). Özellikle 1990'lı yıllardan sonra, tıbbi ve aromatik bitkilerin yeni kullanım alanlarının bulunması ve doğal ürünlere olan talebin artması ile bu bitkilerin kullanım hacmi her geçen gün artmaktadır. 2000 yılında tıbbi ve aromatik bitkiler piyasasının yıllık yaklaşık 60 milyar dolarlık bir pazar payına sahip olduğu kaydedilmiştir; bu rakam dünyadaki yıllık ilaç pazarının yaklaşık \%20'sini oluşturmaktadır (Suzer, 2005). Bitkisel ilaçların kişi başına en yüksek tüketiminin olduğu ülke Japonya'dır (Anonymous, 2016).

Tibbi bitkisel ürünlere artan talep ulusal ve uluslararası bir trentdir. Gida korumada kullanılan kimyasal maddelere yasal sinirlamalar getirilmesi nedeniyle, bitkilerden elde edilen ve antioksidan olarak kullanılabilen uçucu yağlara olan talep her geçen gün artmaktadır. Bitkisel ürünlerin, sentetik ilaçların aksine çok az yan etkisi olan, güvenli ve sağlıklı ürünler olarak kabul edilmesi de pazar payının büyümesine yardımcı olan önemli bir faktördür. 
Bitkisel ürünler ve ilaçlar son on yıl içerisinde, dünya genelindeki ekonomik durgunluğa rağmen kayda değer büyüme göstermiştir (Kartal ve Erdem, 2012).Sektörün her gün biraz daha yükselen bir değeri olup, çok sayıdaki diğer alanlar ve iş kollar ile doğrudan veya dolaylı ilişsi içerisindedir. Son yıllarda doğal ürünlere ilgi ve talep artmakta, gıda ve ilaçta sentetik katkılar yerine doğal ve bitkisel kaynaklı katkıların kullanımı tercih edilmektedir. Ülkemizde bu alanda çok sayıda araştırma yapılmamış olup daha çok veri ve bilgilere ihtiyaç duyulmaktadır.

\section{MATERYAL ve METOT}

Araştırma materyali ikincil verilerden oluşmaktadır. Türkiye İstatistik Kurumu (TÜİK), Birleşmiş Milletler Gıda ve Tarım Örgütü (FAO), Uluslararası Ticaret Merkezi (ITC) kayıtları ile Tarım ve Ormancılık Bakanlığı yayın ve dokümanları, kongre ve sempozyum bildirileri, tez, makale ve yayınlar, mülakat ve gezi notları oluşturmaktadır.
İkincil veriler TUIK, FAO ve ITC kayttlarından tarama, süzme ve gruplandırma usulüyle elde edilen veriler Çizelgelerde yıllar itibariyle ürünlere göre üretim alanı, üretim miktarı, ithalat ve ihracat değer ve miktarları özetlentmiş hem üretim hem de ihracat ve ithatta yıllara göre değişimler \% olarak ifade edilmiştir. Ayrıca dış ticarette ülke payları \% olarak hesaplanmıştır.

\section{BULGULAR ve TARTIŞMA}

Dünya Tıbbi ve Aromatik Bitkileri Üretimi ve Ticareti Dünyada tıbbi ve aromatik bitkilerden önemli bir bölümünün üretim alanları ve miktarları FAO istatistiklerinde bitkisel üretim başlığ $\breve{l}_{1}$ altında diğer bitkisel ürünlerle karışık şekilde verilmiştir. Üretim alanlarının büyüklüğü yönüyle yeşil kahve, kakao, çay, keten, karabuğday ilk sıralarda yer almaktadır. Alan bakımından 2002-2014 yılları arasında önemli artışlar gözlenirken özellikle keçiboynuzunda \%36’yı bulan bir düşüş olduğu görülmektedir (Çizelge 1).

Çizelge 1. Bazı tıbbi ve aromatik bitkilerin yıllara göre dünya üretim alanı (ha)

\begin{tabular}{|c|c|c|c|c|c|c|}
\hline Ürünler & $\begin{array}{c}2002 \\
\text { (ha) }\end{array}$ & $\begin{array}{c}2005 \\
\text { (ha) }\end{array}$ & $\begin{array}{c}2010 \\
\text { (ha) }\end{array}$ & $\begin{array}{l}2013 \\
\text { (ha) }\end{array}$ & $\begin{array}{l}2014 \\
\text { (ha) }\end{array}$ & $\begin{array}{c}\text { Değişim } \\
2002-2014\end{array}$ \\
\hline Yeşil kahve & 10.441 .895 & 10.680 .009 & 10.519 .456 & 10.601 .185 & 10.485 .408 & 0 \\
\hline Kakao çekirdekleri & 7.013 .710 & 8.722 .033 & 9.620 .443 & 10.176 .019 & 10.434 .201 & 49 \\
\hline Çay & 2.439 .543 & 2.681 .472 & 3.145 .178 & 3.616 .412 & 3.799 .831 & 56 \\
\hline Keten tohumu & 2.428 .390 & 2.816 .481 & 2.089 .090 & 2.240 .569 & 2.625 .156 & 8 \\
\hline Karabuğday & 2.070 .057 & 2.485 .578 & 1.910 .635 & 2.274 .644 & 2.011 .289 & -3 \\
\hline Kuru biber ve Şili biberi & 1.933 .888 & 1.813 .112 & 1.881 .893 & 1.948 .656 & 1.688 .082 & -13 \\
\hline Anason, rezene, kişniş & 920.641 & 712.328 & 933.243 & 1.083 .396 & 1.124 .386 & 22 \\
\hline Baharatlar & 619.720 & 739.564 & 966.111 & 1.009 .669 & 916.232 & 48 \\
\hline Hardal tohumu & 798.115 & 719.888 & 792.489 & 656.332 & 812.421 & 2 \\
\hline Karanfil & 489.813 & 467.284 & 389.107 & 564.200 & 567.602 & 16 \\
\hline Zencefil & 329.146 & 361.598 & 268.723 & 367.885 & 396.724 & 21 \\
\hline Tarçın & 154.867 & 175.204 & 229.945 & 259.516 & 269.424 & 74 \\
\hline Mate & 289.429 & 269.551 & 290.703 & 266.392 & 266.000 & -8 \\
\hline Vanilya & 39.252 & 78.699 & 86.265 & 109.122 & 108.607 & 177 \\
\hline Haşhaş tohumu & 106.883 & 104.548 & 149.025 & 96.000 & 102.332 & -4 \\
\hline Şerbetçiotu & 84.735 & 79.588 & 77.512 & 77.499 & 82.985 & -2 \\
\hline Keçiboynuzu & 112.244 & 105.803 & 87.842 & 78.067 & 71.374 & -36 \\
\hline Kenevir tohumu & 28.240 & 24.596 & 16.556 & 23.719 & 24.025 & -15 \\
\hline Nane & 2.681 & 3.145 & 2.774 & 3.684 & 3.507 & 31 \\
\hline
\end{tabular}

Kaynak: FAO, 2017.

Dünyada tıbbi ve aromatik bitkilerin üretim miktarında 2002-2014 yılları arasında keçi boynuzu dışında değişik oranlarda genel bir artış gözlenmektedir. Bu artışta anason, rezene, kişniş ve baharatlar grubu ile tarçın ilk sıralarda yer almaktadır (Çizelge 2).

Tıbbi ve aromatik bitkilerin kayıt altına alınması ve ticareti konusunda tüm dünyada ve ülkemizde ciddi sıkıntılar bulunmaktadır. Dünya literatüründe "Black Market" olarak adlandırılan tıbbi ve aromatik bitkiler piyasasının standardize edilmesi ve kayıt altına alınması konusunda günümüze kadar birçok çalışma yapılmıştır. Bunlardan en başta "International Trade
Centre" (ITC), gelmektedir. ITC diş ticaret istatistiklerinde tıbbi ve aromatik bitkilerinde 3 ana başlık öne çıkmaktadır:

1 -Çay, kahve, mate ve baharat grubunda; kahve, çay, biber, diğer biberler, kırmızıbiberler, vanilya, tarçın ağacı çiçekleri, küçük hindistan cevizi, kakule, anason, yıldız anasonu, rezene, kimyon, zencefil, safran, köri, zerdeçal, kekik ve defne yer almaktadır.

2 -Sakız, reçine, bitki özsuları ve özütleri (ekstraktları) grubunda; meyan kökü, şerbetçi otu, haşhaş, pireotu ve aloe özütleri, arap zamkı ve bazı bitki suları bulunmaktadır. 
3-Uçucu yağlar, parfüm, kozmetik ve diğer kişisel bakım ürünleri grubunda; uçucu yağlar, rezinoidler, terpenik maddeler, koku (parfüm), güzellik (saç, diş) ve kişisel bakım ürünlerinde kullanılan maddeler yer almaktadır.
Dünya kahve, çay, mate ve baharatların ihracatı 2002 yılında 11,7 milyar iken 2015 yll itibariyle 48,3 milyar dolardır olarak gerçekleşmiştir. Bu grup ürünleri ihraç eden ülkelerin başını, Brezilya, Vietnam ve Hindistan çekmektedir. Türkiye ihracatta listeye 168,5 milyon dolarla 32. suradan girebilmiştir (Çizelge 3).

Çizelge 2. Bazı tıbbi ve aromatik bitkilerin yıllara göre dünya üretim miktarı (ton)

\begin{tabular}{|c|c|c|c|c|c|c|}
\hline Ürünler & $\begin{array}{l}2002 \\
\text { (Ton) } \\
\end{array}$ & $\begin{array}{l}2005 \\
\text { (Ton) }\end{array}$ & $\begin{array}{l}2010 \\
\text { (Ton) } \\
\end{array}$ & $\begin{array}{l}2013 \\
\text { (Ton) } \\
\end{array}$ & $\begin{array}{l}2014 \\
\text { (Ton) } \\
\end{array}$ & $\begin{array}{c}\text { Değişim } \\
2002-2014 \\
\end{array}$ \\
\hline Yeşil kahve & 7.991 .432 & 7.451 .720 & 8.484 .744 & 8.890 .919 & 8.790 .005 & 10 \\
\hline Çay & 3.222 .892 & 3.682 .303 & 4.603 .515 & 5.349 .088 & 5.561 .339 & 73 \\
\hline Kakao çekirdekleri & 3.320 .531 & 4.044 .042 & 4.329 .984 & 4.488 .377 & 4.450 .263 & 34 \\
\hline Kuru biber ve Şili biberi & 2.427 .223 & 2.837 .107 & 3.148 .238 & 3.618 .392 & 3.818 .768 & 57 \\
\hline Keten tohumu & 1.921 .662 & 2.757 .272 & 1.817 .249 & 2.280 .096 & 2.654 .432 & 38 \\
\hline Zencefil & 1.179 .807 & 1.368 .089 & 1.691 .811 & 2.423 .324 & 2.156 .453 & 83 \\
\hline Baharatlar & 1.098 .303 & 1.488 .162 & 2.024 .997 & 2.157 .322 & 2.068 .988 & 88 \\
\hline Karabuğday & 1.832 .821 & 2.084 .870 & 1.453 .614 & 2.263 .966 & 1.924 .082 & 5 \\
\hline Anason, rezene, kişniş & 495.669 & 547.681 & 774.025 & 944.728 & 970.404 & 96 \\
\hline Mate & 935.115 & 768.911 & 938.772 & 842.650 & 931.673 & 0 \\
\hline Hardal tohumu & 520.057 & 565.350 & 626.708 & 525.208 & 681.877 & 31 \\
\hline Tarçın & 110.876 & 175.612 & 191.301 & 209.527 & 213.678 & 93 \\
\hline Keçiboynuzu & 208.277 & 179.375 & 168.669 & 133.172 & 156.798 & -25 \\
\hline Karanfiller & 107.548 & 105.054 & 127.456 & 137.010 & 152.968 & 42 \\
\hline Şerbetçiotu & 125.709 & 118.843 & 126.363 & 117.746 & 132.631 & 6 \\
\hline Kenevir tohumu & 62.614 & 101.012 & 57.727 & 89.333 & 102.948 & 64 \\
\hline Nane & 60.840 & 69.050 & 80.731 & 95.117 & 92.295 & 52 \\
\hline Haşhaş tohumu & 51.953 & 75.476 & 98.207 & 70.277 & 83.577 & 61 \\
\hline Vanilya & 5.308 & 7.501 & 8.283 & 8.177 & 7.746 & 46 \\
\hline
\end{tabular}

Kaynak: FAO, 2017.

Çizelge 3. Kahve, çay, mate ve baharatların ülke ve yıllara göre dünya ihracatı $(1.000 \$)$

\begin{tabular}{|c|c|c|c|c|c|c|c|}
\hline \multirow{2}{*}{ No } & \multirow{2}{*}{ Ülkeler } & \multicolumn{4}{|c|}{ Yillar } & \multirow{2}{*}{$\begin{array}{c}\text { Payı } \\
(\%)\end{array}$} & \multirow{2}{*}{$\begin{array}{c}\text { Değişim } \\
(\%)\end{array}$} \\
\hline & & 2002 & 2005 & 2010 & 2015 & & \\
\hline 1 & Brezilya & 1.331 .394 & 2.669 .066 & 5.398 .682 & 6.046 .077 & 12,52 & 354,12 \\
\hline 2 & Vietnam & 527.367 & 1.012 .208 & 2.537 .295 & 4.005 .173 & 8,29 & 659,47 \\
\hline 3 & Hindistan & 680.921 & 898.456 & 2.003.311 & 2.919 .671 & 6,04 & 328,78 \\
\hline 4 & Almanya & 688.887 & 1.327 .052 & 2.394.281 & 2.883 .918 & 5,97 & 318,63 \\
\hline 5 & Kolombiya & 786.214 & 1.497 .878 & 1.921 .672 & 2.585 .926 & 5,35 & 228,91 \\
\hline 6 & Çin & 551.575 & 927.362 & 1.657 .471 & 2.535 .382 & 5,25 & 359,66 \\
\hline 7 & Endonezya & 521.281 & 786.956 & 1.428 .830 & 2.196 .028 & 4,55 & 321,28 \\
\hline 8 & Sri Lanka & 746.230 & 901.424 & 1.549 .491 & 1.666 .549 & 3,45 & 123,33 \\
\hline 9 & İtalya & 340.545 & 602.898 & 1.007 .582 & 1.471 .418 & 3,05 & 332,08 \\
\hline 10 & Kenya & 177.061 & 698.026 & 1.380 .589 & 1.464 .601 & 3,03 & 727,17 \\
\hline 11 & $\mathrm{ABD}$ & 351.325 & 479.345 & 888.103 & 1.219 .454 & 2,52 & 247,10 \\
\hline \multirow[t]{3}{*}{12} & Belçika & 258.805 & 537.685 & 1.113 .935 & 1.209 .834 & 2,50 & 367,47 \\
\hline & Diğerleri & 4.787.377 & 6.748 .176 & 13.621 .896 & 18.098 .795 & 37,47 & 278,05 \\
\hline & Toplam & 11.750 .984 & 19.088 .537 & 36.905 .148 & 48.304 .841 & 100,00 & 311,07 \\
\hline \multicolumn{2}{|c|}{ Kahve Hariç Toplam } & 5.190 .931 & 6.710 .010 & 12.718 .207 & 17.864 .887 & -- & 244 \\
\hline
\end{tabular}

Kaynak: ITC, 2016.

Dünya kahve, çay, mate ve baharatların ithalatı 2002 yılında 12,7 milyar iken 2015 yll itibariyle 48,1 milyar dolar olarak gerçekleşmiştir. Bu grup ürünleri ithal eden ülkelerin başını ABD (\%16,9 payla), Almanya (\%8,9 payla) ve Fransa (\%5,9 payla) çekmektedir. Türkiye ihracatta listeye199,8 milyon dolarla 42. sıradan girmektedir (Çizelge 4).
Dünya sakız, reçine, bitki özsu ve ekstraklarının ihracatı 2002 yılında 2,3 milyar dolardan 2015 yılı sonu itibariyle 7 milyar dolara yükselmiştir. Bu ürün grubu ihracatında ilk sıraları Çin, Hindistan, Almanya ve Amerika Birleşik Devletleri almaktadır. Türkiye 9,1 milyon dolar ihracatla 43. sirayı almaktadır (Çizelge 5). 
Çizelge 4. Kahve, çay, mate ve baharatların ülke ve yıllara göre dünya ithalatı (1.000\$)

\begin{tabular}{|c|c|c|c|c|c|c|c|}
\hline \multirow{2}{*}{ No } & \multirow{2}{*}{ Ülkeler } & \multicolumn{4}{|c|}{ Yillar } & \multirow{2}{*}{$\begin{array}{l}\text { Payı } \\
(\%)\end{array}$} & \multirow{2}{*}{$\begin{array}{c}\text { Değişisim } \\
(\%)\end{array}$} \\
\hline & & 2002 & 2005 & 2010 & 2015 & & \\
\hline 1 & $\mathrm{ABD}$ & 2.338 .759 & 3.641 .134 & 5.942 .352 & 8.176 .661 & 16,98 & 249,62 \\
\hline 2 & Almanya & 1.278 .135 & 2.256 .998 & 4.190 .130 & 4.304 .447 & 8,94 & 236,78 \\
\hline 3 & Fransa & 683.151 & 971.931 & 2.012 .468 & 2.858 .180 & 5,94 & 318,38 \\
\hline 4 & Japonya & 906.795 & 1.353 .760 & 1.877 .336 & 2.126 .804 & 4,42 & 134,54 \\
\hline 5 & İtalya & 474.001 & 823.692 & 1.465 .904 & 1.972 .893 & 4,10 & 316,22 \\
\hline 6 & İngiltere & 614.016 & 769.852 & 1.336 .660 & 1.710 .746 & 3,55 & 178,62 \\
\hline 7 & Hollanda & 384.962 & 576.583 & 911.881 & 1.599 .753 & 3,32 & 315,56 \\
\hline 8 & Kanada & 446.440 & 727.980 & 1.252 .040 & 1.567 .151 & 3,25 & 251,03 \\
\hline 9 & İspanya & 306.271 & 546.278 & 941.313 & 1.331 .640 & 2,77 & 334,79 \\
\hline 10 & Belçika & 358.581 & 619.309 & 1.243 .388 & 1.270 .207 & 2,64 & 254,23 \\
\hline 11 & Rusya & 279.323 & 409.022 & 959.167 & 1.222 .621 & 2,54 & 337,71 \\
\hline \multirow[t]{4}{*}{12} & Arap Emirlikleri & 250.000 & 358.057 & 750.000 & 969.987 & 2,01 & 287,99 \\
\hline & Diğerleri & 4.384 .341 & 6.646 .135 & 12.944 .491 & 19.043 .260 & 39,55 & 334,35 \\
\hline & Toplam & 12.704 .775 & 19.700 .731 & 35.827 .130 & 48.154 .350 & 100,00 & 279,03 \\
\hline & $\begin{array}{l}\text { Kahve Hariç } \\
\text { Toplam }\end{array}$ & 5.593 .107 & 6.699 .465 & 11.909 .587 & 17.388.702 & & 211 \\
\hline
\end{tabular}

Kaynak: ITC, 2016. *Tahmin.

Çizelge 5. Sakız, reçine, bitki özsu ve ekstrakların ülke ve yıllara göre dünya ihracatı (1.000\$)

\begin{tabular}{llrrrrrr}
\hline \multirow{2}{*}{ No } & \multirow{2}{*}{ Ülkeler } & \multicolumn{1}{c}{ Ylllar } & \multicolumn{1}{c}{$\begin{array}{c}\text { Payl } \\
(\%)\end{array}$} & \multicolumn{1}{c}{$\begin{array}{c}\text { Değişim } \\
(\%)\end{array}$} \\
\cline { 2 - 6 } & Cin & 77.125 & 113.318 & 646.249 & 1.272 .173 & 17,96 & 1549,49 \\
2 & Hindistan & 224.196 & 401.920 & 657.568 & 1.063 .198 & 15,01 & 374,23 \\
3 & Almanya & 254.183 & 386.537 & 610.680 & 621.378 & 8,77 & 144,46 \\
4 & ABD & 286.413 & 337.249 & 566.017 & 572.971 & 8,09 & 100,05 \\
5 & Fransa & 214.526 & 370.537 & 470.703 & 526.060 & 7,42 & 145,22 \\
6 & Ispanya & 123.678 & 199.672 & 237.168 & 333.870 & 4,71 & 169,95 \\
7 & Danimarka & 205.709 & 251.382 & 257.890 & 288.755 & 4,08 & 40,37 \\
8 & İtalya & 95.830 & 138.397 & 142.421 & 234.936 & 3,32 & 145,16 \\
9 & Filipinler & 39.162 & 43.947 & 116.682 & 186.691 & 2,63 & 376,71 \\
& Diğerleri & 817.050 & 1.278 .533 & 1.962 .418 & 1.985 .266 & 28,02 & 142,98 \\
& Toplam & 2.337 .872 & 3.521 .492 & 5.667 .796 & 7.085 .298 & 100,00 & 203,07 \\
\hline
\end{tabular}

Kaynak: ITC, 2016.

Dünya sakız, reçine, bitki özsu ve ekstraklarının ithalatı 2002 yılında 2,5 milyar dolardan 2015 yılı sonu itibariyle 76,9 milyar dolara yükselmiştir. Bu ürün grubu ithalatında ilk sıraları Çin, Hindistan, Almanya ve ABD almaktadır. Türkiye 39,5 milyon dolar ihracatla 31. sırayı almaktadır (Çizelge 6).

Dünya uçucu yağlar, parfüm-kozmetik, diğer kişisel bakım ürünlerinin ihracat toplamı 2002 yılında 38 milyar dolarken 2015 yılında 111,4 milyar dolara yükselmiştir. Ihracatçı ülkelerin başında Fransa, ABD, Almanya, İrlanda gelmektedir. Türkiye 695 milyon dolarla 25. sıradadır (Çizelge 7).

Dünya uçucu yağlar, parfüm-kozmetik, diğer kişisel bakım ürünlerinin ithalatı toplamı 2002 yılında 37 milyar dolarken 2015 yılında 111 milyar dolara yükselmiştir. İthalatçı ülkelerin başında Fransa, ABD, Almanya ve İrlanda gelmektedir. Türkiye 695 milyon dolarla 27. sıradadır (Çizelge 8).

Dünya uçucu yağlar, parfüm-kozmetik, diğer kişisel bakım ürünleri grubundan sadece "uçucu yağlar" incelendiğinde ihracatı toplamı 2002 yılında 1,4 milyar dolarken 2015 yılında 5 milyar dolara yükselmiştir. İhracatçı ülkelerin başında Çin, ABD ve Hindistan gelmektedir. Türkiye 33,6 milyon dolarla 23. sıradadır (Çizelge 9).

Uçucu yağlar, parfüm-kozmetik, diğer kişisel bakım ürünleri grubundan sadece "uçucu yağlar" incelendiğinde ithalatı toplamı 2002 yılında 1,6 milyar dolarken 2015 yılında 4,5 milyar dolara yükselmiştir.

İthalatçı ülkelerin başında ABD, Fransa ve İngiltere gelmektedir. Türkiye 26,7 milyon dolarla 26. sıradadır (Çizelge 10).

Tıbbi ve aromatik bitkilerin dünya ticaret hacmi sürekli artmaktadır. Ayrı ayrı 3 grupta incelenmiş olan dünya ticaretine toplu olarak bakıldığında (kahve, çay, mate ve baharatlar-sakız, reçine, bitki özsu ve ekstrakları-uçucu yağlar, parfüm-kozmetik, güzellik, saç, diş ve kişisel bakım ürünleri) toplam ihracatı 2002 yilında 52,4 milyar dolardan 2005 yılında 82 milyar dolara yükselmiştir. 
Daha sonra hizla artarak 2010 yılında 131,3 milyar dolara 2015 yılında bu miktar 166,8 milyar dolara yükselmiştir. İhracat 2002-2015 yılları arasında \%218 artmıştır. Uçucu yağlar, parfüm-kozmetik, güzellik, saç, diş ve kişisel bakım ürünleri ihracatın yarıdan fazlasını oluşturmaktadırlar. Grup içerisinde uçucu yağların payı ise $\% 5$ civarlarındadır. Ithalat ise 2002 yılında 52,2 milyar dolardan 2005 yılında 81,4 milyar dolara yükselmiştir. Daha sonra hızla artarak 2010 yılında 127,2 milyar dolara 2016 yılının başında bu miktar 166,3 milyar dolara yükselmiştir (Çizelge 11).

Aslında dünyada ihracat toplamı ile ithalat toplamının aynı büyüklükte olması beklenmektedir ancak aralarındaki fark ülkelerin dış ticaret hesap hatalarından kaynaklandığı düşünülmektedir. Başka bir deyişle bir ülkenin ihracat ve ithalat miktarı dış ticaret büyüklüğünü oluşturmakta iken dünyada ise dış ticareti kavramı yerine ticaret değeri, ticaret hacmi kavramlarıyla hatalı algılamanın önlenebileceği düşülmektedir. Bu durumda, dünya tıbbi ve aromatik bitkilerin ticaret değeri yaklaşık 166 milyar dolar iken ticaret döngüsü bunun iki katı şeklinde olup yaklaşık 330 milyardır.

Üçüncü grupta sadece uçucu yağlar, (parfümkozmetik, güzellik, saç, diş ve kişisel bakım ürünleri hariç) hesaba katıldığında 2015 yılı ihracatı 60 milyar dolar, ithalatı 59,5 milyar dolar civarında kalmaktadır (Çizelge 12). Kahve, çay, mate ve baharatların dünya genelinde dış ticaret değerleri artmıştır.

Çizelge 6. Sakız, reçine, bitki özsu ve eksraktların ülke ve yıllara göre dünya ithalatı $(1.000 \$)$

\begin{tabular}{|c|c|c|c|c|c|c|c|}
\hline \multirow{2}{*}{ No } & \multirow{2}{*}{ Ülkeler } & \multicolumn{4}{|c|}{ Yillar } & \multirow{2}{*}{$\begin{array}{c}\text { Payı } \\
(\%)\end{array}$} & \multirow{2}{*}{$\begin{array}{l}\text { Değişim } \\
(\%)\end{array}$} \\
\hline & & 2002 & 2005 & 2010 & 2015 & & \\
\hline 1 & ABD & 478.379 & 649.186 & 917.227 & 1.718 .105 & 24,81 & 259,15 \\
\hline 2 & Almanya & 216.210 & 356.603 & 500.617 & 537.309 & 7,76 & 148,51 \\
\hline 3 & Fransa & 140.878 & 241.055 & 274.053 & 345.258 & 4,99 & 145,08 \\
\hline 4 & Japonya & 214.617 & 358.918 & 270.765 & 327.237 & 4,72 & 52,47 \\
\hline 5 & Çin & 36.384 & 62.905 & 120.550 & 227.367 & 3,28 & 524,91 \\
\hline 6 & İngiltere & 120.917 & 163.311 & 186.231 & 219.560 & 3,17 & 81,58 \\
\hline 7 & Hindistan & 28.414 & 54.762 & 117.469 & 197.963 & 2,86 & 596,71 \\
\hline 8 & İtalya & 93.862 & 150.242 & 157.821 & 195.814 & 2,83 & 108,62 \\
\hline 9 & İspanya & 57.024 & 98.249 & 152.234 & 194.310 & 2,81 & 240,75 \\
\hline 10 & Rusya & 40.081 & 43.987 & 134.732 & 167.570 & 2,42 & 318,08 \\
\hline 11 & Kore & 73.223 & 87.054 & 122.952 & 158.156 & 2,28 & 115,99 \\
\hline 12 & Hollanda & 62.050 & 77.157 & 120.466 & 154.396 & 2,23 & 148,83 \\
\hline \multirow[t]{3}{*}{13} & Kanada & 64.773 & 90.485 & 122.563 & 151.349 & 2,19 & 133,66 \\
\hline & Diğerleri & 890.899 & 1.277 .640 & 2.046 .420 & 2.331 .319 & 33,66 & 161,68 \\
\hline & Toplam & 2.517 .711 & 3.711 .554 & 5.244 .100 & 6.925 .713 & 100,00 & 175,08 \\
\hline
\end{tabular}

Kaynak: ITC, 2016.

Çizelge 7. Uçucu yağlar, parfüm-kozmetik, diğer kişisel bakım ürünlerinin ülke ve yıllara göre dünya ihracatı $(1.000 \$)$

\begin{tabular}{clrrrrrr}
\hline \multirow{2}{*}{ No } & Ülkeler & \multicolumn{1}{c}{ Ylllar } & \multicolumn{1}{c}{$\begin{array}{c}\text { Payı } \\
(\%)\end{array}$} & \multicolumn{1}{c}{$\begin{array}{c}\text { Değişim } \\
(\%)\end{array}$} \\
\cline { 2 - 5 } & & \multicolumn{1}{c}{2002} & \multicolumn{1}{c}{2010} & \multicolumn{1}{c}{2015} & \\
\hline 1 & Fransa & 7.872 .857 & 11.519 .599 & 14.451 .943 & 15.117 .599 & 13,56 & 92,02 \\
2 & ABD & 4.443 .012 & 6.015 .800 & 9.094 .029 & 11.808 .302 & 10,59 & 165,77 \\
3 & Almanya & 4.019 .156 & 6.163 .442 & 9.681 .461 & 9.708 .132 & 8,71 & 141,55 \\
4 & İlanda & 2.900 .643 & 6.381 .820 & 7.161 .674 & 8.798 .038 & 7,89 & 203,31 \\
5 & İngiltere & 3.351 .756 & 4.247 .210 & 4.953 .391 & 5.504 .745 & 4,94 & 64,23 \\
6 & Çin & 518.336 & 1.200 .608 & 2.494 .011 & 4.694 .167 & 4,21 & 805,62 \\
7 & Singapur & 661.332 & 1.418 .038 & 3.140 .054 & 4.554 .698 & 4,09 & 588,72 \\
8 & İtalya & 1.732 .190 & 2.779 .466 & 3.393 .581 & 4.382 .316 & 3,93 & 152,99 \\
9 & İpanya & 1.207 .323 & 2.026 .489 & 3.278 .661 & 3.816 .118 & 3,42 & 216,08 \\
10 & Hollanda & 1.080 .021 & 1.810 .392 & 1.951 .350 & 3.463 .013 & 3,11 & 220,64 \\
11 & Belçika & 945.426 & 1.351 .965 & 2.416 .714 & 2.932 .506 & 2,63 & 210,18 \\
12 & Kore & 162.826 & 294.903 & 824.907 & 2.927 .565 & 2,63 & 1697,97 \\
13 & İsviçre & 1.469 .171 & 1.865 .686 & 2.819 .879 & 2.867 .536 & 2,57 & 95,18 \\
14 & Polonya & 396.272 & 964.669 & 2.435 .222 & 2.654 .375 & 2,38 & 569,84 \\
15 & Meksika & 634.454 & 676.492 & 1.776 .648 & 2.356 .864 & 2,11 & 271,48 \\
& Diğerleri & 6.932 .294 & 10.757 .545 & 18.924 .082 & 25.890 .527 & 23,23 & 273,48 \\
& Toplam & 38.327 .069 & 59.474 .124 & 88.797 .607 & 111.476 .501 & 100,00 & 190,86 \\
\hline
\end{tabular}

Kaynak: ITC, 2016. 
Çizelge 8. Uçucu yağlar, parfüm-kozmetik, diğer kişisel bakım ürünlerinin ülke ve yıllara göre dünya ithalatı $\underline{(1.000 \$)}$

\begin{tabular}{|c|c|c|c|c|c|c|c|}
\hline \multirow{2}{*}{ No } & \multirow{2}{*}{ Ülkeler } & \multicolumn{4}{|c|}{ Yillar } & \multirow{2}{*}{$\begin{array}{l}\text { Payı } \\
(\%)\end{array}$} & \multirow{2}{*}{$\begin{array}{l}\text { Değişim } \\
(\%)\end{array}$} \\
\hline & & 2002 & 2005 & 2010 & 2015 & & \\
\hline 1 & $\mathrm{ADB}$ & 3.366 .393 & 6.875 .344 & 8.242 .518 & 12.083 .750 & 10,86 & 258,95 \\
\hline 2 & Almanya & 2.691 .282 & 4.151 .180 & 5.739 .525 & 7.047 .991 & 6,33 & 161,88 \\
\hline 3 & İngiltere & 2.996 .607 & 4.455 .771 & 5.344 .177 & 6.428 .265 & 5,78 & 114,52 \\
\hline 5 & Fransa & 2.364 .897 & 3.517 .667 & 4.933 .222 & 5.299 .605 & 4,76 & 124,09 \\
\hline 4 & Çin & 201.104 & 500.506 & 1.502 .226 & 4.509 .560 & 4,05 & 2142,40 \\
\hline 6 & Hong Kong (Çin) & 847.181 & 1.138 .827 & 2.163 .392 & 4.013 .049 & 3,61 & 373,69 \\
\hline 8 & Kanada & 1.447 .042 & 1.921 .428 & 2.711 .265 & 3.292 .699 & 2,96 & 127,55 \\
\hline 7 & Hollanda & 1.030 .945 & 1.560 .601 & 2.199 .351 & 3.215 .393 & 2,89 & 211,89 \\
\hline 9 & İspanya & 1.442 .650 & 2.299 .814 & 2.807 .364 & 3.111 .446 & 2,80 & 115,68 \\
\hline 12 & Italya & 1.632 .094 & 2.519 .379 & 2.934 .466 & 2.812 .938 & 2,53 & 72,35 \\
\hline 11 & Japonya & 1.517 .466 & 2.121 .028 & 2.840 .770 & 2.799 .124 & 2,52 & 84,46 \\
\hline 10 & Singapur & 683.581 & 1.162 .020 & 1.911 .854 & 2.674 .209 & 2,40 & 291,21 \\
\hline 14 & Meksika & 834.368 & 1.162 .557 & 1.640 .239 & 2.666 .440 & 2,40 & 219,58 \\
\hline 15 & Rusya & 691.129 & 1.418 .707 & 3.153 .482 & 2.629 .627 & 2,36 & 280,48 \\
\hline 13 & Belçika & 896.688 & 1.364 .369 & 2.058 .835 & 2.569 .074 & 2,31 & 186,51 \\
\hline \multirow[t]{3}{*}{16} & B. Arap Emirlikleri & & 955.321 & & 2.520 .748 & 2,27 & \\
\hline & Diğgerleri & 14.370 .097 & 20.944 .871 & 35.986 .430 & 43.585 .331 & 39,17 & 203,31 \\
\hline & Toplam & 37.013 .524 & 58.069 .390 & 86.169 .116 & 111.259 .249 & 100,00 & 200,59 \\
\hline
\end{tabular}

Kaynak: ITC, 2016.

Çizelge 9. Uçucu yağların ülke ve yıllara göre dünya ihracatı (1.000\$)

\begin{tabular}{|c|c|c|c|c|c|c|c|}
\hline \multirow{2}{*}{ No } & \multirow{2}{*}{ Ülkeler } & \multicolumn{4}{|c|}{ Yillar } & \multirow{2}{*}{$\begin{array}{c}\text { Payı } \\
(\%)\end{array}$} & \multirow{2}{*}{$\begin{array}{c}\text { Değişim } \\
(\%)\end{array}$} \\
\hline & & 2002 & 2005 & 2010 & 2015 & & \\
\hline 1 & Çin & 68.694 & 84.580 & 190.728 & 793.598 & 13,88 & 1055,27 \\
\hline 2 & $\mathrm{ABD}$ & 312.498 & 351.707 & 431.583 & 598.495 & 10,46 & 91,52 \\
\hline 3 & Hindistan & 63.610 & 143.281 & 334.650 & 572.995 & 10,02 & 800,79 \\
\hline 4 & Fransa & 161.931 & 204.485 & 276.508 & 355.201 & 6,21 & 119,35 \\
\hline 5 & Brezilya & 78.608 & 105.706 & 165.903 & 256.877 & 4,49 & 226,78 \\
\hline 6 & İngiltere & 88.698 & 106.348 & 190.574 & 243.714 & 4,26 & 174,77 \\
\hline 7 & Arjantin & 67.130 & 96.718 & 127.811 & 224.655 & 3,93 & 234,66 \\
\hline 8 & Endonezya & 51.366 & 64.601 & 124.718 & 179.905 & 3,15 & 250,24 \\
\hline 9 & Almanya & 42.826 & 69.002 & 124.831 & 178.693 & 3,12 & 317,25 \\
\hline 10 & Hollanda & 16.412 & 29.198 & 25.213 & 143.632 & 2,51 & 775,16 \\
\hline 11 & Meksika & 28.490 & 44.516 & 65.042 & 137.558 & 2,41 & 382,83 \\
\hline 12 & İtalya & 40.942 & 49.836 & 104.238 & 132.492 & 2,32 & 223,61 \\
\hline \multirow[t]{3}{*}{13} & İspanya & 36.219 & 54.218 & 78.459 & 125.807 & 2,20 & 247,35 \\
\hline & Diğerleri & 482.889 & 518.419 & 923.503 & 1.775 .886 & 31,05 & 267,76 \\
\hline & Toplam & 1.540 .313 & 1.922 .615 & 3.163 .761 & 5.719 .508 & 100,00 & 271,32 \\
\hline
\end{tabular}

Kaynak: ITC, 2016.

Türkiye'nin bu gelişime paralellik gösterdiği görülmektedir. Ancak ihracatta dünya ortalamasının altında kalırken ithalatta dünya ortalamasının çok üzerindedir. $\mathrm{Bu}$ durum, Türkiye'nin kahve ithalatındaki önemli miktardaki artışıla açıklanabilir. Sakız, reçine, bitki özsuları ve ekstraktlarının dünyada ticari değeri artmıştır. Türkiye'nin bu grupta dış ticareti dünya ortalamasıyla benzerlik göstermektedir. Uçucu yağlar, parfüm- kozmetik, güzellik, saç, diş ve kişisel bakım ürünlerinin ticaretinde dünyada önemli bir artış olmuştur.

Türkiye dış ticarette dünya ortalamasının üzerinde yer almıştır. $\mathrm{Bu}$ grup işlenmiş ve yarı işlenmiş mamullerden oluşmaktadır. Grubun ticari değerinin büyüklüğü işlenmiş ürün olmasından gelmektedir. Sermaye ve teknoloji kullanımı hammadde şeklindeki ürünlere katma değer kazandırmıştır. 
Çizelge 10. Uçucu yağların ülke ve yıllara göre dünya ithalatı (1.000\$)

\begin{tabular}{|c|c|c|c|c|c|c|c|}
\hline \multirow{2}{*}{ No } & \multirow{2}{*}{ Ülkeler } & \multicolumn{4}{|c|}{ Yillar } & \multirow{2}{*}{$\begin{array}{l}\text { Payı } \\
(\%)\end{array}$} & \multirow{2}{*}{$\begin{array}{c}\text { Değişim } \\
(\%)\end{array}$} \\
\hline & & 2002 & 2005 & 2010 & 2015 & & \\
\hline 1 & ABD & 301.976 & 390.888 & 570.845 & 987.623 & 21,86 & 227,05 \\
\hline 2 & Fransa & 168.729 & 199.407 & 285.944 & 379.769 & 8,41 & 125,08 \\
\hline 3 & İngiltere & 150.488 & 182.169 & 243.325 & 326.138 & 7,22 & 116,72 \\
\hline 4 & Almanya & 97.410 & 117.242 & 202.231 & 322.693 & 7,14 & 231,27 \\
\hline 5 & Çin & 49.656 & 64.532 & 120.663 & 228.330 & 5,05 & 359,82 \\
\hline 6 & Hollanda & 41.542 & 45.872 & 85.980 & 178.837 & 3,96 & 330,50 \\
\hline 7 & Hindistan & 16.478 & 30.056 & 97.206 & 160.506 & 3,55 & 874,06 \\
\hline 8 & Japonya & 96.008 & 152.304 & 156.516 & 155.689 & 3,45 & 62,16 \\
\hline 9 & İrlanda & 29.103 & 75.225 & 44.949 & 146.464 & 3,24 & 403,26 \\
\hline 10 & İsviçre & 72.929 & 103.403 & 135.129 & 138.462 & 3,06 & 89,86 \\
\hline 11 & İspanya & 45.173 & 60.921 & 101.193 & 136.733 & 3,03 & 202,69 \\
\hline 12 & Singapur & 25.023 & 61.208 & 118.877 & 132.688 & 2,94 & 430,26 \\
\hline 13 & Kanada & 40.818 & 36.628 & 53.931 & 117.849 & 2,61 & 188,72 \\
\hline \multirow[t]{3}{*}{14} & Endonezya & 8.926 & 13.629 & 47.180 & 114.912 & 2,54 & 1187,39 \\
\hline & Diğerleri & 474.521 & 500.670 & 767.945 & 991.148 & 21,94 & 108,87 \\
\hline & Toplam & 1.618 .780 & 2.034 .154 & 3.031 .914 & 4.517 .841 & 100,00 & 179,09 \\
\hline
\end{tabular}

Kaynak: ITC, 2016.

Çizelge 11. Tibbi ve aromatik bitkilerin ürünlere göre dünya ticareti (1.000\$)

\begin{tabular}{|c|c|c|c|c|c|c|c|}
\hline \multirow{2}{*}{ Şekli } & \multirow{2}{*}{ Ürünler } & \multicolumn{4}{|c|}{ Yillar } & \multirow{2}{*}{$\begin{array}{c}\text { Payl } \\
(\%)\end{array}$} & \multirow{2}{*}{$\begin{array}{l}\text { Değişim } \\
(\%)\end{array}$} \\
\hline & & 2002 & 2005 & 2010 & 2015 & & \\
\hline \multirow{4}{*}{ 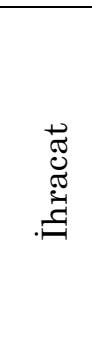 } & $\begin{array}{l}\text { Kahve, çay, mate ve } \\
\text { baharatlar }\end{array}$ & 11.748 .982 & 19.086 .532 & 36.903 .138 & 48.302 .826 & 28,95 & 311 \\
\hline & $\begin{array}{l}\text { Sakız, reçine, bitki özsu ve } \\
\text { ekstrakları }\end{array}$ & 2.337 .872 & 3521492 & 5.667 .796 & 7.085.298 & 4,25 & 203 \\
\hline & $\begin{array}{l}\text { Uçucu yağlar, parfüm- } \\
\text { kozmetik, güzellik, saç, diş } \\
\text { ve kişisel bakım ürünleri }\end{array}$ & 38.327 .069 & 59.474 .124 & 88.797 .607 & 111.476 .501 & 66,81 & 191 \\
\hline & Toplam & 52.413 .923 & 82.082 .148 & 131.368 .541 & 166.864 .625 & 100,00 & 218 \\
\hline \multirow{4}{*}{. } & $\begin{array}{l}\text { Kahve, çay, mate ve } \\
\text { baharatlar }\end{array}$ & 12.704 .775 & 19.700 .731 & 35.827 .130 & 48.154 .350 & 2,95 & 279 \\
\hline & $\begin{array}{l}\text { Sakız, reçine, bitki özsu ve } \\
\text { ekstrakları }\end{array}$ & 2.517 .711 & 3.711 .554 & 5.244 .100 & 6.925 .713 & 4,16 & 175 \\
\hline & $\begin{array}{l}\text { Uçucu yağlar, parfüm- } \\
\text { kozmetik, güzellik, saç, diş } \\
\text { ve kişisel bakım ürünleri }\end{array}$ & 37.013 .524 & 58.069 .390 & 86.169 .116 & 111.259 .249 & 66,89 & 201 \\
\hline & Toplam & 52.236 .010 & 81.481 .675 & 127.240 .346 & 166.339 .312 & 100,00 & 218 \\
\hline
\end{tabular}

Kaynak: ITC, 2016.

Türkiye Tıbbi ve Aromatik Bitkileri Üretimi ve Ticareti

Birçok tıbbi ve aromatik bitki, ev bahçelerinde, tarlalarda ve az da olsa plantasyon şeklinde yetişmektedir. Dünyada, ticari amaçlarla 900 kadar tıbbi bitki kültürü yapılmaktadır ve kültürü yapılan bitki sayısı çok sinırlıdır (Arslan ve ark., 2015). Türkiye İstatistik Kurumunun (TUIK) tarafindan yayınlanan istatistiki verilerde tıbbi ve aromatik bitkiler başlığı altında özel bir sınıflandırma bulunmamaktadır. Tıbbi ve aromatik bitkiler diğer gruplara serpiştirilmiş olup içerisinde bazılarının yer aldığı kayıtlar ancak 2012 yılından itibaren tutulmaya başlanılmıştır.

Bir kısmı endüstri bitkiler sınıfına bir kısmı yağlı tohumlar sınıfına bir kısmı sebzeler kısmına ve bir kısmı ise baharat bitkileri grubuna dahil edilmektedir. $\mathrm{Bu}$ bitkiler ile üretim alanları ve miktarları Çizelge 13 'de verilmiştir. Buna göre 1.332.542 dekar alanda tıbbi ve aromatik bitki grubuna giren yaklaşık 20 çeşit bitkinin yetiştiriciliği yapılmaktadır. Siyah çay dahil edildiğinde 2.094.615 dekar alana ulaşmaktadır.. 
Çizelge 12. Tıbbi ve aromatik bitkilerin ürünlere (bazı ürünler hariç) göre dünya ticareti (1.000\$)

\begin{tabular}{|c|c|c|c|c|c|c|c|}
\hline \multirow{2}{*}{ Şekli } & \multirow{2}{*}{ Ürünler } & \multicolumn{4}{|c|}{ Yillar } & \multirow{2}{*}{$\begin{array}{c}\text { Payı } \\
(\%)\end{array}$} & \multirow{2}{*}{$\begin{array}{l}\text { Değişim } \\
(\%)\end{array}$} \\
\hline & & 2002 & 2005 & 2010 & 2015 & & \\
\hline \multirow{4}{*}{ 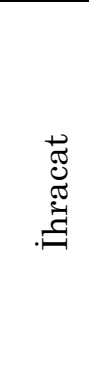 } & $\begin{array}{l}\text { Kahve, çay, mate ve } \\
\text { baharatlar }\end{array}$ & 11.748 .982 & 19.086 .532 & 36.903 .138 & 48.302 .826 & 80,09 & 311 \\
\hline & $\begin{array}{l}\text { Sakız, reçine, bitki özsu ve } \\
\text { ekstrakları }\end{array}$ & 2.337 .872 & 3521492 & 5.667 .796 & 7.085 .298 & 11,75 & 203 \\
\hline & $\begin{array}{l}\text { Uçucu yağlar, (parfüm- } \\
\text { kozmetik, güzellik, saç, diş } \\
\text { ve kişisel bakım ürünleri } \\
\text { hariç) }\end{array}$ & 1.471 .619 & 1.838 .035 & 2.973 .033 & 4.925 .910 & 8,17 & 235 \\
\hline & Toplam & 15.558 .473 & 24.446 .059 & 45.543 .967 & 60.314 .034 & 100,00 & 288 \\
\hline \multirow{4}{*}{ 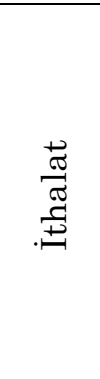 } & $\begin{array}{l}\text { Kahve, çay, mate ve } \\
\text { baharatlar }\end{array}$ & 12.704 .775 & 19.700 .731 & 35.827 .130 & 48.154 .350 & 80,80 & 279 \\
\hline & $\begin{array}{l}\text { Sakız, reçine, bitki özsu ve } \\
\text { ekstrakları }\end{array}$ & 2.517 .711 & 3.711 .554 & 5.244 .100 & 6.925 .713 & 11,62 & 175 \\
\hline & $\begin{array}{l}\text { Uçucu yağlar, (parfüm- } \\
\text { kozmetik, güzellik, saç, diş } \\
\text { ve kişisel bakım ürünleri } \\
\text { hariç) }\end{array}$ & 1.618 .780 & 2.034 .154 & 3.031 .914 & 4.517 .841 & 7,58 & 179 \\
\hline & Toplam & 16.841 .266 & 25.446 .439 & 44.103 .144 & 59.597 .904 & 100,00 & 254 \\
\hline
\end{tabular}

Kaynak: ITC, 2016.

Genel anlamda, günümüzde tıbbi ve aromatik bitki üretim alanı, 2000'li yıllara göre \%40 oranında artış göstermiştir. Yine bazı bitkilerin birim alan verimlerinin arttığı gözlenmiştir. Yeni bitkiler yetiştirme kültürüne girerken bazı kadim bitkilerin ise tarımı ya çok azalmış ya da bitmiştir. Haşhaş, kimyon, safran, keten, kenevir eski zamanlardan beri tarımı yapılan bitkilerdir. Sonra zamanla şerbetçi otu, kekik, anason, rezene, çemen, kırmızıbiber, çay, kudret narı, çörek otu, nane, biberiye, lavanta, ada çayı, kapari, ekinezya, limon melisa, çöven, papatya, reyhan, kişniş, ısırgan otu, fesleğen gibi bitkiler kültüre alınmıştır. Daha birçok bitki henüz yeni kültüre alınmış veya alınma çalışmaları devam etmektedir. Halen soğanlı tıbbi bitkiler, yabani kekik türleri, kantaron doğadan toplanmaktadır. Keten, kenevir ve safranın kültürel üretimi nedeyse bitmek üzeredir. Son yılların popüler bitkisi şeker otunun ise kültüre alma çalışmaları devam etmektedir.

Türkiye, florasının çeşitliliği ve bu florada yer alan endemik bitkiler açısından, dünyanın en zengin ülkelerinden birisidir. Bu kadar zengin bir floraya sahip bir ülkede bitkilerden faydalanmamak söz konusu olamaz. Yerel tüketim amaç ile ülkemizin her bölgesinde doğadan bitki toplanmaktadır. Bunun yansıra hem yurt içi kullanım hem de yurt dışına ihracat amacı ile de doğadan bitki toplama işlemi bilinçli ya da bilinçsiz bir şekilde yapılmaktadır. Doğadan bitki toplama işleminin bilinçsiz bir şekilde yapılması bazı bitkilerin yok olma tehdidi ile karşı karşıya kalmaya neden olmuştur. Gün geçtikçe toplanan miktarlardaki artış tehdit altına giren bitki sayısında ve çeşitliliğinde de artışı beraberinde getirmektedir.
Çoğunluğu orman sahası içerisinde yetiştirilen tıbbi bitkilerin ticareti 6831 saylı Orman Kanunu çerçevesinde yönetilmektedir. Bu kanuna göre devlet ormanlarında üretim (orman sahalar) içinden elde edilen tüm ürünler üretim olarak kabul edilir) Genel Müdürlük tarafından tespit edilen esaslar kapsamında 37. ve 40. madde hükümlerine göre yapılmakta veya yaptırılmaktadır. Orman sahalarından bitki toplanması izne tabidir ve bölgedeki Orman Bölge Şefliklerine rüsum (bir çeşit vergi) ödenmesi gerekmektedir.

Odun dışı orman ürünü olarak toplanan 30'a yakın tıbbi ve aromatik bitki çeşidi bulunmakta olup, defne yaprağı, kekik, keçiboynuzu ilk sıralarda yer almaktadır. Son yıllarda, 90'lı yıllara göre elde edilen defne, keçiboynuzu, ıhlamur miktarları artarken kekik, laden ve çalba miktarları düşmüştür. Kantaron, karabaş otu, lavanta gibi bitkilerin ise orman alanlarından elde edildiği bilinmekle beraber miktarları kayıtlara sağlıklı olarak geçmediği düşünülmektedir (Çizelge 14). Türkiye'nin tıbbi ve aromatik bitkiler ihracatı yıllara göre değişmekle birlikte 50'ye yakın bitki ve bitki grubunda 279,2 milyon dolar olarak gerçekleşmektedir.

$\mathrm{Bu}$ bitkiler dış ticaret verilerinde bir sınıf altında veya düzen dahilinde verilmemektedir. Gümrük Tarife İstatistik Pozisyonunun (GTIP) değişik sayfalarına serpiştirilmiştir. Hatta bazıları "diğerleri" kapsamında yer aldığı için adları veya ürün grupları ve miktarları tam olarak belirlenememektedir. Türkiye'nin yıllar itibariyle tıbbi ve aromatik bitkiler ihracatı Çizelge 15'de verilmiştir. 
Çizelge 13. Türkiye'de yıllara göre tıbbi ve aromatik bitkiler ekim alanı ve üretim durumu

\begin{tabular}{|c|c|c|c|c|c|c|c|c|c|c|c|}
\hline \multirow{2}{*}{$\begin{array}{c}\text { Sira } \\
\text { No }\end{array}$} & \multirow{2}{*}{ Bitki Adı } & \multicolumn{2}{|c|}{2000} & \multicolumn{2}{|c|}{2006} & \multicolumn{2}{|c|}{2012} & \multicolumn{2}{|c|}{2015} & \multicolumn{2}{|c|}{ Değişim \% } \\
\hline & & Dekar & Ton & Dekar & Ton & Dekar & Ton & Dekar & Ton & Alan & Ton \\
\hline 1 & Siyah Çay & 767.500 & 758.038 & 766.136 & .121 .206 & 758.566 & 1.250 .000 & 762.073 & 1.327 .934 & -1 & 75 \\
\hline 2 & Kırmızıbiber & 80.940 & 21.340 & 66.960 & 45.861 & 112.677 & 165.527 & 112.887 & 204.131 & 39 & 857 \\
\hline 3 & Haşhaş & 275.550 & 11.564 & 420.238 & 27.443 & 135.106 & 3.497 & 615.919 & 30.730 & 124 & 166 \\
\hline 4 & Kimyon & 135.300 & 6.900 & 211.540 & 11.998 & 226.294 & 13.900 & 270.247 & 16.897 & 100 & 145 \\
\hline 5 & Nane & 6.960 & 5.000 & 9.894 & 9.591 & 10.469 & 12.598 & 10.577 & 14.945 & 52 & 199 \\
\hline 6 & Kekik & 52.500 & 7.000 & 58.853 & 7.979 & 94.284 & 11.598 & 104.863 & 12.992 & 100 & 86 \\
\hline 7 & Gül (yağlık) & 17.360 & 6.589 & $17.000^{*}$ & $8.400 *$ & 30.832 & 10.225 & 28.243 & 33 & 63 & 44 \\
\hline 8 & Anason & 360.000 & 20.000 & 126.542 & 8.479 & 194.430 & 11.023 & 138.118 & 9.050 & -62 & -55 \\
\hline 9 & Dere Otu & 1.770 & 1.700 & 2.601 & 2.456 & 3.259 & 2.901 & 4.777 & 4.488 & 170 & 164 \\
\hline 10 & Süpürge Otu & - & - & - & - & - & - & 15.035 & 2.078 & - & - \\
\hline 11 & Şerbetçi Otu & 3.180 & 740 & 2.677 & 1.384 & 3.442 & 1.752 & 3.500 & 1.869 & 10 & 153 \\
\hline 12 & $\operatorname{Re}$ & - & - & - & - & 15.775 & 1.862 & 15.512 & 1.461 & -2 & 1361 \\
\hline 13 & Çöre & - & - & - & - & 2.299 & 161 & 4.681 & 425 & 104 & 325 \\
\hline 14 & Acı $\mathrm{E}$ & 4.500 & 355 & 6.011 & 482 & 4.681 & 423 & 3.742 & 409 & -17 & 15 \\
\hline 15 & Lav & - & - & - & - & 509 & 123 & 3.218 & 400 & 532 & 225 \\
\hline 16 & Oğul Otu & - & - & - & - & 450 & 238 & 512 & 242 & 14 & 2 \\
\hline 17 & Ada Çayı & - & - & - & - & 54 & 7 & 536 & 19 & 893 & 171 \\
\hline 18 & Kişn & - & - & - & - & 11 & 1 & 150 & 11 & 1264 & 1000 \\
\hline 19 & $\mathrm{Ka}$ & - & - & - & - & - & - & 15 & - & - & - \\
\hline 20 & Otu & - & - & - & - & 3 & 0,42 & 0 & 0 & - & - \\
\hline 21 & Keter & 3.203 & 173 & 1448 & 84 & 180 & 13 & 0 & 0 & -100 & -100 \\
\hline 22 & $\mathrm{Ke}$ & 8.750 & 140 & 650 & & 64 & & 10 & 1 & -100 & -100 \\
\hline & Toplam & 1.717 .513 & & 1.673 .550 & & 1.593 .385 & & 2.094 .615 & & 22 & \\
\hline & $\begin{array}{l}\text { Çay hariç } \\
\text { Toplam }\end{array}$ & 950.013 & & 907.414 & & 834.819 & & 1.332 .542 & & 40 & \\
\hline
\end{tabular}

Kaynak: TÜİK, 2016a; http://www. koop.gtb.tr / açıklama; *2008 yılı.

İhracatı 49 kalem, drog ve drog grubu ve yapışan ve kıvam artırıcı maddeler, özütler (keçiboynuzu, meyan özü, siyam baklası, saluz adası mastikası, kitre, arap zamkı, zamk sakız reçineleri, diğer reçineler ve diğerleri (1), özsu ve hülasaları kahve, çay, şerbetçi otu ve diğerleri (2), çeşni ve lezzet verici diğer karışımlardan (3) oluşmaktadır. Drog ve drog grubu ithalatın \%79,7'sini oluştururken diğer grup ise $\% 21,3$ 'ini oluşturmaktadır. Baharat, ilaç, kozmetik ve kimya sektörü başta olmak üzere pek çok kullanım alanı bulunan kekik, ülkemizin tıbbi ve aromatik bitkiler dış ticareti içerisinde önemli bir yere sahiptir. Türkiye, dünya kekik ticaretinin yaklaşık \%70-80'ini elinde bulundurmaktadır. İhracatta ilk sırayı kekik almakta ve toplam drog ihracatmin \%25'ini oluşturmaktadır. Kekik ihracatı 2002 yılında 8.256 ton karşılığ 13,3 milyon dolar iken 2015yılında 15.225 ton karşılığ 55,9 milyon dolara yükselmiştir. Bu değişim fiziksel olarak \%84, değer olarak \%320 olmuştur. İhracatta \%17 payla ikinci sırayı alma haşhaş almaktadır. Haşhaşın hem tohumu, hem de alkaloitleri önemli ihraç ürünlerindendir. Haşhaşın tohum halinde ihracatından 37,6 milyon dolar elde edilmektedir. Meyve kabuğundan 20'ye yakın alkaloid elde edilmektedir. Bunlar afyon türevleri olan morfin, kodein gibi uyuşturucu ve tıpta da ağrı kesici, uyku verici olarak kullanılmaktadır. Alkaloitler Çizelge 15'de yer almamakla beraber yıllık 40-45 milyon dolar ihracatı gerçekleşmektedir.

Afyon'un Bolvadin ilçesinde kurulu bulunan ve yıllık 20.000 ton kapsül işleme kapasitesine sahip Afyon Alkaloidleri Fabrikasında işlenerek yurtiçi ihtiyacını karşıladıktan sonra \%95'lik kısmı ihraç edilmekte ve dünya ihtiyacının \%30'unu karşlamaktadır (Eken, 2004).Defne yapraklarından elde edilen uçucu yağ ilaç ve kozmetik sanayiinde kullanılır. Aynı zamanda çay olarak ve yemeklerde lezzet-koku verici olarak kullanılır. Defne yaprağı ihracatı, 2002 yılında 13.125 ton karşılığında 21 milyon dolar iken 2015 yılında \%2 azalarak 12.855 tona düşmüş ancak ihracat değeri \%72 artarak 36 milyon dolara yükselmiştir. Defneyaprağı üretimi, Orman Genel Müdürlüğ̈’nün 302 Sayılı Tebliğ esaslarına ve yıllık üretim programlarına göre düzenlenmekte olup (Anonim, 2016).

Üretime 6831 Sayılı Orman Kanunu'nun 37. maddesine göre izin verilmekte, toplama Orman Genel Müdürlügü'nün gözetim ve denetimi altında tarife bedeli karşılığında devlet ormanlarından yararlanma hakları olan orman köylüleri ve kooperatiflerince yapılmaktadır (Yıldırım, 2011).

Siyah çay ihracatta \%10'luk bir paya sahip olup 2002 yılında 509 ton iken \%1000 artışla 2015 yılında 5.441 tona ulaşmıştır. 
Çizelge 14. Türkiye'nin odun dışı orman ürünü olarak elde edilen tibbi ve aromatik bitkiler üretimi

\begin{tabular}{|c|c|c|c|c|c|c|c|c|}
\hline $\begin{array}{l}\text { Tibbi ve Aromatik } \\
\text { Bitkileri (Tali) }\end{array}$ & $\begin{array}{l}1990 \\
\text { (ton) }\end{array}$ & $\begin{array}{l}1995 \\
\text { (ton) }\end{array}$ & $\begin{array}{l}2000 \\
\text { (ton) }\end{array}$ & $\begin{array}{l}2005 \\
\text { (ton) }\end{array}$ & $\begin{array}{l}2010 \\
\text { (ton) }\end{array}$ & $\begin{array}{l}2014 \\
\text { (ton) }\end{array}$ & $\begin{array}{l}2015 \\
\text { (ton) }\end{array}$ & $\begin{array}{l}\text { Değişisim \% } \\
2000-2015\end{array}$ \\
\hline Defne Yaprağ & 852 & 3126 & 5738 & 8564 & 15418 & 15581 & 21634 & 277 \\
\hline Kekik & 1165 & 2728 & 3692 & 974 & 1412 & 2493 & 2119 & -42 \\
\hline Laden & - & 152 & 1186 & 606 & 332 & 307 & 748 & -36 \\
\hline Keçiboynuzu & - & - & 82 & 207 & 322 & 539 & 614 & 648 \\
\hline Adaçayı & 195 & 411 & 341 & 441 & 702 & 342 & 578 & 69 \\
\hline Mersin Yaprağı & - & - & 58,7 & 1190 & 415,8 & 458,2 & 489,6 & 734 \\
\hline Biberiye & 81 & 398 & 238 & 46 & - & 172 & 278 & 16 \\
\hline Yosun & - & - & 122,3 & 103,6 & 116,5 & 74,2 & 238,2 & 94 \\
\hline Tavşan Memesi & - & - & 126,3 & 220,8 & 75,7 & 122,7 & 132,7 & 5 \\
\hline Çalba & 1 & - & - & 378 & 114 & 81 & 110 & -243 \\
\hline Göl Soğanı & - & - & 23,5 & - & 5,6 & - & 70 & 197 \\
\hline Erika & - & - & - & 57 & - & 29,5 & 50,5 & -12 \\
\hline Ihlamur & 17 & 5 & 14 & 12 & 194 & 50 & 48 & 242 \\
\hline Kardelen Soğanı & - & - & 22,5 & 22,2 & 19,2 & 34,5 & 23,6 & 4 \\
\hline Sarmaşık & - & - & 2,5 & 16,5 & 186,2 & 7,5 & 21 & 740 \\
\hline Eğrelti Otu & 1 & - & 5 & 25 & 49 & 24 & 19 & 280 \\
\hline Reçine & - & - & 4,4 & - & - & 3 & 3 & -31 \\
\hline Yoğurt Çiçeği Soğanı & - & - & 9,2 & 67,5 & 7,4 & 54,5 & 2,2 & -76 \\
\hline Oğul Otu & - & 1 & 1 & - & - & - & 2 & - \\
\hline Papatya & - & - & - & - & - & - & 1 & - \\
\hline Ada Soğanı & - & - & 0,5 & - & 2,4 & - & 0,5 & - \\
\hline Kantaron* & - & - & - & 1 & 1 & - & - & - \\
\hline Ökse otu & - & - & - & - & 18 & - & - & - \\
\hline Isırgan Otu & - & - & - & - & 51 & 9 & - & - \\
\hline Lavanta & - & - & - & 4 & 1 & - & - & - \\
\hline Karabaş Otu** & - & - & - & 1 & 2 & 1 & - & - \\
\hline Katır Tırnağı & - & 3 & & - & 3 & - & - & - \\
\hline Yayla Çayı & - & - & 1 & - & - & - & - & - \\
\hline Sığla Yağı & 2 & - & 3,2 & 1,2 & 3 & - & - & - \\
\hline Kitre $* * *$ & - & - & - & - & 6,6 & - & 1 & - \\
\hline Liken & - & - & - & - & - & 1,2 & - & - \\
\hline
\end{tabular}

Kaynak: OGM, 2016; TÜİK, 2016a. Açıklama:*2007yılı 1 ton, 2008 yılı 1 ton; ** 2006 yılı 1 ton, 2007 yllı 1 ton, 2012 yılı 1 ton; ***2012 yıll 6,6 ton, 213 yılı 1 ton.

2002 yllında 4.731 dolar iken \%380 artışla 22,7 milyon dolara yükselmiştir. Anason, bitkinin tohumlarından elde edilir. Rakı gibi alkollü içeceklere çeşni katmak için kullanılır. Tatlılarda da kullanılır. Anason drog ihracatının yaklaşık \%5'ini oluşturur. Anason ihracatı 2002 yılında 2.916 ton ve 4,9 milyon gerçekleşmiştir. 2015 yllında \%11 artarak 3.250 ton, değer olarak \%136 artarak 11,5 milyon dolar gerçekleşmiştir. Kimyon bir baharat olup ihracatın \%5’i kadardır. Kimyon ihracatı hem miktar hem de değer olarak 2000'li yıllara göre düşmüştür. Adaçayı, genellikle bitkisel çay olarak ve et yemeklerine koku ve lezzet vermek amaciyla kullanılmaktadır. İhracat payı \%3,6 olup 2015 yılında 2.070 ton ve 8 milyon dolar olarak gerçekleşmiştir. Adaçayı ada çayının 2015 yılında 19 ton tarla üretiminden 838 tonu ithalattan olmak üzere geriye kalanı ise doğadan toplamayla elde edilmektedir. İ̧ tüketimle ne kadar tüketildiği bilinmemektedir.

Kahve Türkiye'de ekolojik nedenle tarımı yapılmayan bir bitki olup ihracatı ise ithalat yoluyla elde edilen kahveden oluşmaktadır. Genellikle işlenerek ihraç edilmektedir. 2015 yllında 7 milyon dolarlık kahve ihracatı gerçekleştirilmiştir. Mahlep kurak şartlarda yetişen çalı formunda ve doğal bir bitkidir. Kurutulan meyveleri baharat ve hamur işlerine hoş koku, gevreklik vermek amacıyla kullanılır. Mahlep ihracatı 2015 yılında 2002 yılına göre $\% 756$ artarak 4,3 milyon dolar olmuştur. Kırmızıbiber ihracatı 2002 yılında 5,3 milyon dolardan 2015 yılına kadar \%25 azalarak 4 milyon dolara düşmüştür.

Rezene ihracat verileri son yıllarda anason kayıtları içerisinde verilmeye başlanmıştır. Ancak rezene ihracatı 2002 yılından 2010 yılına kadar miktar olarak $\% 50$ düşmesine rağmen 1,2 milyon dolardan \%100 artarak 2,4 milyon dolara yükselmiştir. Karabiber, keçiboynuzu, meyan kökü, nane, yeşil çay, sumak, ıhlamur, köri, kişniş, çöven, biberiye, vanilya, çörekotu, çemen, tarçın, günlük, karanfil, zencefil, yenibahar, keten, kenevir, zerdeçal, safran, kakule, küçük hindistan cevizi, tatlı biber, hindiba, güve otu, vermut otu ihracatı yapılan diğer bitkilerdir. 
Çizelge 15. Türkiye'nin ylllar itibariyle başlıca tıbbi ve aromatik bitkiler ihracatı

\begin{tabular}{|c|c|c|c|c|c|c|c|c|c|}
\hline \multirow[b]{2}{*}{ Bitki Adı } & \multicolumn{2}{|c|}{2002} & \multicolumn{2}{|c|}{2010} & \multicolumn{2}{|c|}{2015} & 2015 & \multicolumn{2}{|c|}{ Değişisim } \\
\hline & $\begin{array}{l}\text { Miktar } \\
\text { (Ton) }\end{array}$ & $\begin{array}{c}\text { Değer } \\
(1000 \$)\end{array}$ & $\begin{array}{l}\text { Miktar } \\
\text { (Ton) }\end{array}$ & $\begin{array}{c}\text { Değer } \\
(1000 \$)\end{array}$ & $\begin{array}{l}\text { Miktar } \\
\text { (Ton) }\end{array}$ & $\begin{array}{c}\text { Değer } \\
(1000 \$)\end{array}$ & $\begin{array}{l}\text { Payı } \\
\%\end{array}$ & $\begin{array}{l}\text { Ton } \\
\%\end{array}$ & $\begin{array}{l}\text { Değer } \\
\%\end{array}$ \\
\hline Kekik & 8256 & 13321 & 12957 & 28141 & 15225 & 55980 & 25,46 & 84,41 & 320,24 \\
\hline Haşhaş & 17638 & 15499 & 16300 & 52317 & 12126 & 37693 & 17,14 & $-31,25$ & 143,20 \\
\hline Defne & 13125 & 21008 & 8891 & 25618 & 12855 & 36127 & 16,43 & $-2,06$ & 71,97 \\
\hline Siyah Çay & 509 & 4731 & 2164,5 & 8578 & 5441 & 22743 & 10,34 & 968,96 & 380,72 \\
\hline Anason & 2916 & 4913 & 924 & 5376 & 3250 & 11589 & 5,27 & 11,45 & 135,88 \\
\hline Kimyon & 23728 & 24760 & 7695 & 17814 & 3770 & 11150 & 5,07 & $-84,11$ & $-54,97$ \\
\hline Adaçayı & 1537 & 3098 & 1643 & 6148 & 2070 & 8065 & 3,67 & 34,68 & 160,33 \\
\hline Kahve & 131 & 602 & 322 & 3868 & 780 & 7164 & 3,26 & 495,42 & 1090,03 \\
\hline $\begin{array}{l}\text { Mahlep } \\
\text { Diŏ er Bitki }\end{array}$ & 73 & 507 & 53 & 485 & 187 & 4339 & 1,97 & 156,16 & 755,82 \\
\hline $\begin{array}{l}\text { Kisım } \\
\text { (çaylar) }\end{array}$ & 3107 & 4925 & 1040 & 3066 & 1315 & 4073 & 1,85 & $-57,68$ & $-17,30$ \\
\hline $\begin{array}{l}\text { Kirmızı } \\
\text { Biber }\end{array}$ & 1657 & 5365 & 783 & 2698 & 1272 & 4018 & 1,83 & $-23,23$ & $-25,11$ \\
\hline Rezene & 1730 & 1222 & 857 & 2427 & * & * & & & \\
\hline Diğerleri & 11739,6 & 7624,5 & 6236,65 & 21124,5 & 5363,85 & 16961,3 & 7,71 & $-54,31$ & 122,46 \\
\hline Toplam & 86146,6 & 107575,5 & 59866,15 & 177660,5 & 63654,85 & 219902,3 & 100,00 & $-26,11$ & 104,42 \\
\hline 1 & 1400 & 1500 & 720 & 3194 & 1196 & 8162 & 13,75 & -15 & 444 \\
\hline 2 & 67 & 762 & 256 & 6520 & 7915 & 23741 & 39,99 & 11.713 & 3016 \\
\hline 3 & 1102 & 1978 & 8094 & 17231 & 18599 & 27468 & 46,27 & 1.588 & 1289 \\
\hline Toplam & 2569 & 4240 & 9070 & 26945 & 27710 & 59371 & 100 & 979 & 1300 \\
\hline $\begin{array}{l}\text { Genel } \\
\text { Toplam }\end{array}$ & $88.715,60$ & 111.816 & $68.936,20$ & 204.606 & $91.365,00$ & $279.273,00$ & 100,00 & 3,00 & 150 \\
\hline
\end{tabular}

Kaynak: TÜİK, 2016b. *Rezene ihracatı verisi anasonun içesinde yer almaktadır.

1-Yapışan ve kıvam artırıcı maddeler, özütler (keçiboynuzu, meyan özü, siyam baklası, kitre, saloz adası mastikası, arap zamkı, zamk sakız reçineleri, diğer reçineler ve diğerleri),

2-Özsu ve hülasaları (kahve, çay, şerbetçi otu ve diğerleri),

3-Çeşni ve lezzet verici diğer karışımlar.

Yapışan ve kıvam artırıcı maddeler, özütler (keçiboynuzu, meyan özü, siyam baklası, saluz adası mastikası, kitre, arap zamkı, zamk sakız reçineleri, diğer reçineler ve diğerleri) ihracatı, 2002 yılında 1,5 milyon dolar iken 2015 yılında 8,1 milyon dolara ulaşmıştır. Özsu ve hülasaları (kahve, çay, şerbetçi otu ve diğerleri) ihracatı, 2002 yılında 0,7 milyon dolar iken 2005 yılında 1,3 milyon dolara, 2010 yılında 6,5 milyon dolara, 2015 yılında 23,7 milyon dolara yükselmiştir. Çeşni ve lezzet verici diğer karışımlar ihracatı, 2002 yılında 1,9 milyon dolar iken, 2005 yılında 8,7 milyon dolara, 2010 yilında 17,2 milyon dolara ve 2015 yılında 27,4 milyon dolara ulaşmıştır.

Türkiye'nin yıllar itibariyle tıbbi ve aromatik bitkiler ithalatı Çizelge 16 'da verilmiştir. Kahve, tarçın, zerdeçal, karanfil, zencefil, karabiber, kına, vanilya, küçük hindistan cevizi, ginseng gibi bitkilerin Türkiye'de yetiştirilmesi mümkün olmadığı için ithalatı zorunlu olarak yapılmaktadır. Ülkemizde yetiştirilen geleneksel ürünlerinde ithal edildiği görülmektedir. Bir kısmı üretiminin yetersizliğinden bir kısmı maliyetinin daha düşük olmasından bir kısmı da reeksport yapılmasından dolayı ithal edilmektedir. İthalatı 49 kalem, drog ve drog grubu ve yapışan ve kıvam artırıcı maddeler, özütler (keçiboynuzu, meyan özü, siyam baklası, saluz adası mastikası, kitre, arap zamkı, zamk sakız reçineleri, diğer reçineler ve diğerleri (1), özsu ve hülasaları kahve, çay, şerbetçi otu ve diğerleri (2), çeşni ve lezzet verici diğer karışımlardan (3) oluşmaktadır. Drog ve drog grubu ithalatın \%60'1nı oluştururken diğer grup ise \%40'ını oluşturmaktadır. İthalatın ilk sırasını 146,7 milyon dolar ve \%61'lik payla kahve almaktadır. Kahve ekolojik nedenle Türkiye'de yetiştirilememektedir. İthalatı zorunlu bir üründür. Kahve ithalatı, 2002 yılından 2015 yılına kadar $\% 1000$ 'lık artış göstermektedir. Bazı siyah çay çeşitleri (seylan çayı vb.), karabiber, tarçın, zerdeçal, karanfil, zencefil, kakule, vanilya, keten, kenevir, ginseng kökü, safran, kına, küçük hindistan cevizinin Türkiye'de üretimleri hemen hemen hiç yapılmadığından dışalımla tedarik edilmektedir. $\mathrm{Bu}$ bitkilerin ithalatına 2015 yılında toplam 46,5 milyon dolar ödeme yapılmıştır. 
Çizelge 16. Türkiye'nin ylllar itibariyle başlıca tıbbi ve aromatik bitkiler ithalatı

\begin{tabular}{|c|c|c|c|c|c|c|c|c|c|}
\hline \multirow[b]{2}{*}{ Bitki Adl } & \multicolumn{2}{|c|}{2002} & \multicolumn{2}{|c|}{2010} & \multicolumn{2}{|c|}{2015} & 2015 & \multicolumn{2}{|c|}{ Değişim } \\
\hline & $\begin{array}{l}\text { Miktar } \\
\text { (Ton) }\end{array}$ & $\begin{array}{c}\text { Değer } \\
(1000 \$)\end{array}$ & $\begin{array}{l}\text { Miktar } \\
\text { (Ton) }\end{array}$ & $\begin{array}{c}\text { Değer } \\
(1000 \$)\end{array}$ & $\begin{array}{l}\text { Miktar } \\
\text { (Ton) }\end{array}$ & $\begin{array}{c}\text { Değer } \\
(1000 \$)\end{array}$ & $\begin{array}{l}\text { Payı } \\
\%\end{array}$ & $\begin{array}{c}\text { Ton } \\
\%\end{array}$ & $\begin{array}{l}\text { Değer } \\
\%\end{array}$ \\
\hline Kahve & 13857 & 13146 & 19370 & 58919 & 46151 & 146799 & 61,32 & 233,05 & 1016,68 \\
\hline Siyah Çay & 1492 & 2625 & 8217 & 20878 & 5649 & 16914 & 7,07 & 278,62 & 544,34 \\
\hline Keten & 45 & 10 & 4988 & 2616 & 36907 & 16896 & 7,06 & 81915,56 & 168860,00 \\
\hline Kara Biber & 2640 & 3630 & 3559 & 6882 & 3127 & 5658 & 2,36 & 18,45 & 55,87 \\
\hline Keçiboynuzu & 500 & 249 & 851 & 773 & 4912 & 5038 & 2,10 & 882,40 & 1923,29 \\
\hline $\begin{array}{l}\text { Kimyon } \\
\text { Diğer }\end{array}$ & 143 & 222 & 191 & 336 & 1791 & 4439 & 1,85 & 1152,45 & 1899,55 \\
\hline $\begin{array}{l}\text { Bitkisel } \\
\text { Ürün } \\
\text { (Tarifsiz) }\end{array}$ & 325 & 130 & 4730 & 1998 & 10264 & 4324 & 1,81 & 3058,15 & 3226,15 \\
\hline $\begin{array}{l}\text { Diğer Bitki } \\
\text { Kısım } \\
\text { (çaylar) }\end{array}$ & 354 & 367 & 1060 & 2162 & 1657 & 4030 & 1,68 & 368,08 & 998,09 \\
\hline Kekik & 1048 & 1151 & 985 & 2.148 & 1348 & 3875 & 1,62 & 28,63 & 236,66 \\
\hline Tatlı Biber & & & 281 & 710 & 1519 & 3700 & 1,55 & \#SAYI/0! & \#SAYI/0! \\
\hline Defne & 16 & 18 & 510 & 889 & 2302 & 3455 & 1,44 & 14287,50 & 19094,44 \\
\hline Çörekotu & 764 & 270 & 2601 & 1.884 & 2898 & 3017 & 1,26 & 279,32 & 1017,41 \\
\hline Anason & 33 & 57 & 1305 & 3.498 & 1041 & 2594 & 1,08 & 3054,55 & 4450,88 \\
\hline Diğerleri & 6106,55 & 6352,11 & 9789,51 & 15383,76 & 11758,05 & 18647 & 7,79 & 92,55 & 193,56 \\
\hline Toplam & 27323,55 & 28227,11 & 58437,51 & 119076,76 & 131324,05 & 239386 & 100,00 & 380,63 & 748,07 \\
\hline 1 & 1785 & 6828 & 4380 & 14639 & 4727 & 19491 & 12,13 & 165 & 185 \\
\hline 2 & 4701 & 44964 & 8676 & 80167 & 13716 & 118857 & 73,97 & 192 & 164 \\
\hline 3 & 2250 & 5589 & 3129 & 13774 & 6575 & 22337 & 13,90 & 192 & 300 \\
\hline Toplam & 8736,0 & 57381,0 & 16185,0 & 108580,0 & 25018,0 & 160685,0 & $\begin{array}{r}100,00 \\
(40)\end{array}$ & 186 & 180 \\
\hline $\begin{array}{l}\text { Genel } \\
\text { Toplam }\end{array}$ & 36059,6 & 85608,1 & 74622,5 & 227656,8 & 156342,1 & 400071,0 & 100,00 & 334 & 368 \\
\hline $\begin{array}{l}\text { Kahve Hariç } \\
\text { G. Toplam }\end{array}$ & 22202,6 & 72462,1 & 55252,5 & 168737,8 & 110191,1 & 253272,0 & & 400 & 250 \\
\hline
\end{tabular}

Kaynak: TÜİ, 2016b. *Rezene ithalat verisi anasonun içesinde yer almaktadır.

1-Yapışan ve kıvam artırıcı maddeler, özütler (keçiboynuzu, meyan özü, siyam baklası, saluz adası mastikası, kitre, arap zamkı, zamk sakız reçineleri, diğer reçineler ve diğerleri),

2-Özsu ve hülasaları (kahve, çay, şerbetçi otu ve diğerleri),

3-Çeşni ve lezzet verici diğer karışımlar.

Defnede büyük oranda ithalat artışı meydana gelmiştir, 2015 yılında 2.300 ton karşılığında 3,5 milyon dolarlık defneyaprağı ithalatı yapılmıştır. Dünyanın en büyük kaliteli defne üreticisi olan Türkiye, aynı zamanda defneyaprağı dışsatımı yapan birkaç ülkeden birisidir. Gürcistan ve Suriye defneyaprağı ithalatı yapılan önemli ülkeler arasındadır. Gürcistan defnesi, Avrupa tarafindan tercih edilen özellikte bir ürün olduğundan reeksport amacıyla ithalatı yapılmaktadır (Öztürk ve ark., 2016). Şerbetçi otu her ne kadar kozmetik ve ilaç sanayinde kullanılsa da asıl endüstri konusu içecek (biracılık) sanayidir. Kozalakların lupulin ihtiva etmektedir, lupulin biranın bitter ve aromasinı vermektedir (Temel ve ark., 2014). Şerbetçi otu, ithalatı yıllara göre fazla değişmemekle birlikte 2015 yılında 2,1 milyon dolar olarak gerçekleşmiştir. Ihlamur ithalatı, 2000'li yıllarda neredeyse hiç yokken 2015 yılında 105 tona ve 398.000 dolara çıkmıştır.
İhracatında ise yıllara göre bir düşüş yaşamaktadır. Üretimi ise yıllara göre dalgalanmaktadır. Üretimi sadece orman alanlarından çiçek ve yaprak toplama (kesme) usulüyle yapılmaktadır. İhracatın azalması ve ithalatın artışı üretiminin iç tüketimi karşılamakta zorlandığını göstermektedir. Yapışan ve kıvam artırıcı maddeler, özütler (keçiboynuzu, meyan özü, siyam baklası, saluz adası mastikası, kitre, arap zamkı, zamk sakız reçineleri, diğer reçineler ve diğerleri) ithalatı, 2002 yılında 6,8 milyon dolar iken 2015 yılında 19,4 milyon dolara ulaşmıştır. Özsu ve hülasaları (kahve, çay, şerbetçi otu ve diğerleri) ithalatı, 2002 yılında 50 milyon dolar iken 2005 yılında 90 milyon dolara yükselmiş, 2010 yılında 80 milyon dolara düşmüş ve 2015 yılında 119 milyon dolara yükselmiştir. Çeşni ve lezzet verici diğer karışımlar ithalatı, 2002 yılında 5,5 milyon dolar iken, 2005 yılında 9,4 milyon dolara, 2010 yılında 13,7 milyon dolara ve 2015 yılında 22,3 milyon dolara ulaşmıştır. 


\section{Türkiye'nin Uçucu Yağlar Dış Ticareti}

Uçucu yağlar aromatik bitkilerden su buharı damitması ile elde edilen, oda sıcaklığında sıvı olan, bazen donabilen, uçucu, kuvvetli kokulu ve yağımsı karışımlardır. Uçucu yağlar açıkta bırakıldığında oda sıcaklığında bile buharlaşabildiğinden bunlara uçucu (eterik) yağ denilmektedir. Bugün doğada yetişen 300'e yakın bitki familyasından yaklaşık 1/3'ü uçucu yă̆ içermektedir (Anonim, 2013). Uçucu yă̆ içeren bitkiler bakımından oldukça zengin bir floraya sahip olan ülkemizde yüzlerce farklı uçucu yağ bitkisi doğal olarak yetişmekle birlikte bazı bitkilerin tarımı da yapılmaktadır. Uçucu yağlar ve aromatik ekstreler, koku ve tat endüstrileri tarafindan parfüm, gıda katkıları, temizlik ürünleri, kozmetikler ve ilaçların terkibinde, aroma kimyasallarının kaynağ olarak, ya da doğala özdeş ve yarı-sentetik yararlı aroma kimyasallarının sentez başlangıç maddesi olarak kullanılırlar (Başer, 1998).

İlaç, gıda, meşrubat, parfüm ve kozmetik sanayi yanında, özellikle son yıllarda aromaterapi uygulamaları ve tarımsal üretimde de kullanılmaya başlaması, uçucu yağlara olan talebi artırmaktadır. Insektisit, fungisit, herbisit ve nematosit olarak, doğal mücadele kaynağ ${ }_{1}$ şeklinde kullanımlarının yanında; hayvansal üretimde, kanatlılarda ve arıcılıkta son zamanlarda kullanım alanı bulmuştur (Başer, 2000). Gida korumada kullanılan kimyasal maddelere yasal sinırlamalar getirilmesi nedeniyle, bitkilerden elde edilen ve antioksidan olarak kullanılabilen uçucu yağlara olan talep her geçen gün artmaktadır.

Türkiye'nin uçucu yağ ihracatı yıllara göre değişmekle birlikte 17'ye yakın ürün ve ürün grubunda 33,6 milyon dolar olarak gerçekleşmiştir. Türkiye'nin yıllar itibariyle uçucu yağ ihracatı Çizelge 17 'de verilmiştir. Uçucu yağ ihracatı, 2002 yllında 11,6 milyon dolar iken 2010 yllında 17,4 milyon dolara toplamda \%190 artarak 2015 yılında 33,6 milyon dolara ulaşmıştır.

Uçucu yağ üretim ve ihracatının büyük bir kısmını gülyağı oluşturmaktadır. Gülyağı ve gül konkreti aynı Gümrük Tarife İstatistik Pozisyon (GTIP) numarası ile ihraç edilmektedir. Türkiye gülyağı üretiminde dünyada söz sahibi ülkelerin başında gelmektedir. Gülyağı ihracatı, uçucu yağ ihracatının yaklaşık $\% 36$ 'sını oluşturmaktadır.

Türkiye'nin yıllar itibariyle önemli ülkelere göre uçucu yağlar ihracatı Çizelge 18'de verilmektedir. Buna göre, uçucu yağlar ihracatımızın çok önemli bir kısmının Avrupa Birliği ülkelerine yönelik olduğu ifade edilebilir.

Çizelge 17. Türkiye'nin yıllar itibariyle uçucu yağ ihracatı

\begin{tabular}{lrrrrrrrr}
\hline Uçucu Yağlar & $\begin{array}{r}2002 \\
(\$)\end{array}$ & $\begin{array}{r}2005 \\
(\$)\end{array}$ & $\begin{array}{r}2010 \\
(\$)\end{array}$ & $\begin{array}{r}2013 \\
(\$)\end{array}$ & $\begin{array}{r}2014 \\
(\$)\end{array}$ & $\begin{array}{r}2015 \\
(\$)\end{array}$ & $\begin{array}{r}\text { Payl } \\
\%\end{array}$ & $\begin{array}{r}\text { Değişim } \\
\%\end{array}$ \\
\hline Gül & 8.067 .787 & 7.174 .393 & 9.157 .202 & 10.748 .439 & 13.961 .163 & 10.793 .466 & 35,90 & 33,78 \\
Stearopten & 1.534 .253 & 3.117 .897 & 358.924 & 1.420 .055 & 3.814 .944 & 3.495 .880 & 11,63 & 127,86 \\
Kekik & 404.656 & 1.104 .060 & 1.233 .420 & 2.561 .309 & 3.128 .775 & 3.458 .059 & 11,50 & 754,57 \\
Diğerleri & 1.388 .765 & 1.624 .457 & 4.702 .348 & 7.968 .802 & 8.698 .545 & 12.317 .275 & 40,97 & 786,92 \\
Toplam (a) & 11.395 .461 & 13.020 .807 & 15.451 .894 & 22.698 .605 & 29.603 .427 & 30.064 .680 & 100,00 & 163,83 \\
1 & 67.654 & 466.803 & 1.178 .992 & 2.170 .047 & 2.414 .635 & 3.201 .000 & 90,37 & 4631,43 \\
2 & 95.794 & 964.003 & 832.224 & 249.215 & 138.210 & 283.362 & 8,00 & 195,80 \\
3 & 48.497 & 345.168 & 24.330 & 33.159 & 34.207 & 46.747 & 0,87 & $-3,61$ \\
4 & 1.753 & 71.640 & 5.060 & 3.114 & 72.831 & 26.938 & 0,76 & 1436,68 \\
Toplam (b) & 213.698 & 1.847 .614 & 2.040 .606 & 2.455 .535 & 2.659 .883 & 3.558 .047 & $(11) 100$ & 1565 \\
Genel & 11.609 .159 & 14.868 .421 & 17.492 .500 & 25.154 .140 & 32.263 .310 & 33.622 .727 & $(100) 100$ & 190 \\
Toplam(a+b) & & & & & & & &
\end{tabular}

Kaynak: TÜİK, 2016b. *Diğer Turunçgiller; **Güve otu

1-Uçucu yağların enflurage/maceration suretiyle elde edilen konsantreleri,

2-Uçucu yağların damıtılmış suları ve sulu çözeltileri,

3-Rezinoitler ve uçucu yağlardan terpenin alınmasıyla arda kalan yan ürünler,

4-Ekstraksiyonla elde edilen yağ reçineleri.

Çizelge18. Türkiye'nin yıllar itibariyle önemli ülkelere göre uçucu yağlar ihracatı

\begin{tabular}{|c|c|c|c|c|c|c|c|c|c|}
\hline \multirow{2}{*}{ Ülkeler } & \multicolumn{2}{|c|}{2002} & \multicolumn{2}{|c|}{2005} & \multicolumn{2}{|c|}{2010} & \multicolumn{2}{|c|}{2015} & \multirow{2}{*}{$\begin{array}{c}2002-2015 \\
\text { Değişim }\end{array}$} \\
\hline & $(\$)$ & (\%) & $(\$)$ & $(\%)$ & $(\$)$ & (\%) & $(\$)$ & $(\%)$ & \\
\hline Fransa & 7.798 .386 & 67,17 & 7.391 .802 & 49,71 & 9.959 .643 & 56,94 & 20.507 .223 & 60,99 & 162,97 \\
\hline Almany & 1.558 .591 & 13,4 & 2.236 .879 & 15,04 & 2.789 .648 & 15,95 & 2.384 .820 & 7,09 & 53,01 \\
\hline İsviçre & 620.545 & 5,35 & 709.454 & 4,77 & 754.602 & 4,31 & 1.393 .319 & 4,14 & 124,53 \\
\hline $\mathrm{ABD}$ & 540.697 & 4,66 & 568.528 & 3,82 & 762.330 & 4,36 & 1.299 .713 & 3,87 & 140,38 \\
\hline Irlanda & 191.658 & 1,65 & 205.745 & 1,38 & 0 & 0,00 & 0 & 0,00 & $-100,00$ \\
\hline Diğerleri & 899.282 & 7,75 & 3.756 .013 & 25,26 & 226.277 & 18,44 & 8.037 .652 & 23,91 & 793,79 \\
\hline Toplam & 11.609 .159 & 100,00 & 14.868 .421 & 100,00 & 17.492 .500 & 100,00 & 33.622 .727 & 100,00 & 189,62 \\
\hline
\end{tabular}

Kaynak: TÜİK, $2016 \mathrm{~b}$. 
Çizelge 19. Türkiye'nin yıllar itibariyle başlıca uçucu yağlar ithalatı

\begin{tabular}{lrrrrrrrr}
\hline Uçucu Yağlar & $2002(\$)$ & $2005(\$)$ & $2010(\$)$ & $2013(\$)$ & $2014(\$)$ & $2015(\$)$ & Payı \% & Değişim \% \\
\hline Nane & 1.161 .335 & 2.726 .973 & 1.850 .601 & 2.631 .500 & 2.787 .061 & 2.787 .343 & 16,70 & 140,01 \\
Portakal & 378.084 & 663.683 & 788.128 & 1.681 .796 & 2.283 .784 & 2.328 .681 & 13,95 & 515,92 \\
Limon & 262.748 & 377.504 & 709.787 & 848.235 & 1.479 .481 & 1.630 .761 & 9,77 & 520,66 \\
D.Turunçgiller* & 89.376 & 120.790 & 702.671 & 1.027 .713 & 1.194 .730 & 1.023 .723 & 6,13 & 1045,41 \\
Gül & - & 2.542 & 151.106 & 195.291 & 330.449 & 404.333 & 2,42 & - \\
Oğulotu & 944.116 & 225.381 & 226.012 & 260.403 & 604.869 & 275.517 & 1,65 & $-70,82$ \\
Lavanta & 123.821 & 220.515 & 133.955 & 142.888 & 210.884 & 195.967 & 1,17 & 58,27 \\
Diğerleri & 1.303 .856 & 2.384 .379 & 4.140 .363 & 12.494 .523 & 14.372 .225 & 8.048 .205 & 48,21 & 517,26 \\
Toplam (a) & 4.263 .336 & 6.721 .767 & 8.702 .623 & 19.282 .349 & 23.263 .483 & 16.694 .530 & 100,00 & 291,58 \\
1 & 600.230 & 462.094 & 789.085 & 2.543 .352 & 2.705 .581 & 4.629 .594 & 46,15 & 671,30 \\
2 & 159.394 & 582.219 & 747.558 & 1.127 .662 & 1.280 .021 & 3.804 .864 & 37,93 & 2287,08 \\
3 & 274.776 & 692.590 & 1.766 .627 & 1.820 .439 & 2.031 .081 & 1.408 .679 & 14,04 & 412,66 \\
4 & 7.001 & 19.974 & 149.466 & 181.455 & 198.350 & 188.981 & 1,88 & 2599,34 \\
Toplam (b) & 1.041 .401 & 1.756 .877 & 3.452 .736 & 5.672 .908 & 6.215 .033 & 10.032 .118 & $(38) 100$ & 863,33 \\
G. Toplam (a+b) & 5.304 .737 & 8.478 .644 & 12.155 .359 & 24.955 .257 & 29.478 .516 & 26.726 .648 & $(100) 100$ & 403,83 \\
\hline
\end{tabular}

Kaynak: TÜİK, 2016b. *Diğer Turunçgiller

1-Ekstraksiyonla elde edilen yağ reçineleri,

2-Uçucu yağların enflurage/maceration suretiyle elde edilen konsantreleri,

3-Rezinoitler ve uçucu yağlardan terpenin alınmasıyla arda kalan yan ürünler,

4-Uçucu yağların damıtılmış suları ve sulu çözeltileri.

Fransa, Almanya, İsviçre, ABD, İspanya ihracat yapılan en önemli ülkelerdir. Fransa, uçucu yă̆ ihracatında \%61'lik oran ve 20,5 milyon dolarla ilk sıradadır. Türkiye'nin yıllar itibariyle başlıca uçucu yağlar ithalatı Çizelge 19'da verilmiştir.

Çizelge 19 incelendiğinde, 13 yılda uçucu yağlar ithalatında \%400 artış olduğu görülmektedir. Nane, portakal, limon, diğer turunçgiller en önemli ithalatı yapılan uçucu yağlardır. Türkiye'nin uçucu yağ ithalatı yaptığı ülkeler ve değerlerinde yıllara göre önemli değişiklikler söz konusudur. Türkiye'nin ylllar itibariyle önemli ülkelere göre uçucu yağlar ithalatı Çizelge 20'de verilmektedir. İthalat yapılan ülkelerin payları yıllara göre değişmekle beraber, 2015 yılında uçucu yağlar ithalatımızın değer olarak \%15,5’i Hindistan, \%11,5’i Almanya, \%10,40'ı Almanya, \%10’u İspanya ve \%8,20'si Çin'den yapılmaktadır. Sri Lanka'dan yapılan ithalatın değer olarak yıllar itibariyle artmakta olduğu dikkati çekerken; Çin, İtalya, Endonezya, İngiltere ve Brezilya ithalat yapılan diğer önemli ülkeler olarak göze çarpmaktadır. Portakal uçucu yağında; ABD, Brezilya, Almanya ve İngiltere, limon uçucu yağında İspanya, İngiltere ve İtalya, nane uçucu yağında ABD, Almanya ve Fransa, gülyağında Bulgaristan, lavanta uçucu yağında İspanya ve Almanya, oğulotu uçucu yağında Endonezya en fazla ithalat yapılan ülkeler arasındadır (TÜIK, 2016b). Toplam uçucu yağlar ihracat değerlerinde dalgalanmalar olduğu dikkati çekmektedir. $\mathrm{Bu}$ dalgalanmaların büyük ölçüde gülyağı ve stearoptenlerdeki artış ve azalışların sebep olduğu söylenebilir.

\section{SONUÇ}

İnsan sağlığını tehdit eden birçok etmenin temelinde dengesiz beslenme ve dolayısıyla gıda ürünlerinin aşırı ya da az kullanımı yatmaktadır. Bu gelişme ile birlikte modern tıbbın önerdiği kimyasal ilaçların ortaya çıkardığı yan etkileri nedeniyle gelenksel ve tamamlayıcı tıp uygulamalarının sağlık alanında uygulanması ile sağlık sorunlarının üstesinden gelinebileceği oldukça popüler konulardan biri haline gelmiştir. Bu popülarite ile birlikte tıbbi ve aromatik bitkilerin gerek tıp uygulamalarında gerekse de beslenme ihtiyaçlarının karşılanmasında kulanılan miktarları her geçen gün artmaktadır. Dünyada 2000 yılında 50 milyar büyüklüğünde olan tıbbi ve aromatik bitkiler pazarı yaşlanan nüfus, sağlık problemleri, refah artışı, tüketici bilinç artışı ile ivmelenerek 2015 yılında 165 milyar dolara ulaşmış, 2020 yılında 200 milyar dolara ulaşması beklenmektedir.

Dünya tıbbi ve aromatikbitkiler ticaretinde Fransa, ABD, Almanya, İngiltere, Çin, Meksika, İspanya, Brezilya, Hindistan ve Vietnam başı çekmektedir. Türkiye'nin ise ilk 20'de yer almadığı görülmektedir. Dünyada 3500'e yakın bitkinin endemik yeri olan Türkiye'nin bu sektörde güçlü bir konum alması için öncelikle tıbbi ve aromatik bitkilerin tespiti ve sonrasinda da hem tip uygulamalarında hem de beslenme düzenine yerleştirilmesi gereklidir. $\mathrm{Bu}$ çalışma sektörü, ististiksel verilerle ekonomik yönüyle tanıma adına önemli bir görevi yerine getirmiştir.

Türkiye'de 20 çeşit tıbbi ve aromatik bitkinin 1,3 milyon dekar alanda tarımı yapılmakta, üretim miktarı bakımından siyah çay, kırmızıbiber, haşhaş, kimyon, nane, kekik, yağlık gül ve anason ilk sıradadırlar. 
Çizelge 20. Türkiye'nin yıllar itibariyle önemli ülkelere göre uçucu yağlar ithalatı

\begin{tabular}{|c|c|c|c|c|c|c|c|c|c|}
\hline \multirow{2}{*}{ Ülkeler } & \multicolumn{2}{|c|}{2002} & \multicolumn{2}{|c|}{2005} & \multicolumn{2}{|c|}{2010} & \multicolumn{2}{|l|}{2015} & \multirow{2}{*}{$\begin{array}{c}2002-2015 \\
\text { Değişim }\end{array}$} \\
\hline & $(\$)$ & $(\%)$ & $(\$)$ & $(\%)$ & $(\$)$ & $(\%)$ & $(\$)$ & $(\%)$ & \\
\hline Hindistan & 276.428 & 5,21 & 899.301 & 10,61 & 2.182 .180 & 17,95 & 4.138 .293 & 15,48 & 1397,06 \\
\hline Almanya & 665.175 & 12,54 & 912.843 & 10,77 & 1.839 .449 & 15,13 & 3.077 .251 & 11,51 & 362,62 \\
\hline $\mathrm{ABD}$ & 962.741 & 18,15 & 1.835 .420 & 21,65 & 733.861 & 6,04 & 2.783 .206 & 10,41 & 189,09 \\
\hline İspanya & 458.714 & 8,65 & 685.724 & 8,09 & 1.262 .807 & 10,39 & 2.683 .232 & 10,04 & 484,95 \\
\hline Cin & 377.563 & 7,12 & 107.324 & 1,27 & 558.599 & 4,60 & 2.191 .502 & 8,20 & 480,43 \\
\hline Fransa & 937.045 & 17,66 & 1.154 .202 & 13,61 & 1.522 .725 & 12,53 & 2.041 .737 & 7,64 & 117,89 \\
\hline Endonezya & 63.757 & 1,20 & 397.643 & 4,69 & 426.035 & 3,50 & 1.546 .205 & 5,79 & 2325,15 \\
\hline Brezilya & 49.642 & 0,94 & 97.514 & 1,15 & 334.184 & 2,75 & 936.035 & 3,50 & 1785,57 \\
\hline İngiltere & 686.803 & 12,95 & 1.095 .902 & 12,93 & 946.304 & 7,79 & 876.193 & 3,28 & 27,58 \\
\hline İtalya & 130.083 & 2,45 & 386.103 & 4,55 & 721.825 & 5,94 & 753.560 & 2,82 & 479,29 \\
\hline Hollanda & 86.521 & 1,63 & 72.589 & 0,86 & 86.510 & 0,71 & 304.384 & 1,14 & 251,80 \\
\hline Diğer ülkeler & 610.265 & 11,50 & 834.079 & 9,84 & 1.540 .880 & 12,68 & 5.395 .050 & 20,19 & 784,05 \\
\hline Toplam & 5.304 .737 & 100,00 & 8.478 .644 & 100,00 & 12.155 .359 & 100,00 & 26.726 .648 & 100,00 & 403,83 \\
\hline
\end{tabular}

Kaynak: TÜIK, $2016 \mathrm{~b}$

2000'den 2015 yılına üretim alanları yaklaşık \%50 artmıştır, beraberinde üretim daha fazla oranda artmıştır. Yeni bitkiler kültüre alınırken bazı kadim bitkilerin ise tarımı ya çok azalmış ya da bitmiştir. Haşhaş, kimyon, safran, keten, kenevir eski zamanlardan beri tarımı yapılan bitkilerdir. Sonraki zamanlarda şerbetçi otu, kekik, anason, rezene, çemen, kırmızıbiber, çay, kudret narı, çörek otu, nane, biberiye, lavanta, ada çayı, kapari, ekinezya, limon melisa, çöven, papatya, reyhan, kişniş, ısırgan otu, fesleğen gibi bitkiler kültüre alınmıştır. Daha birçok bitki henüz yeni kültüre alınmış veya alınma çalışmaları devam etmektedir. Halen soğanlı tıbbi bitkiler, yabani kekik türleri, kantaron doğadan toplanmaktadır. Keten, kenevir ve safranın tarımı nedeyse bitmek üzeredir. Son yllların popüler bitkisi şeker otu gibi bazı bitkilerin kültüre alma çalışmaları sürmektedir.

Tıbbi ve aromatik bitkileri ihracatı 2002 yılında 112 milyon dolar iken \%150 değişimle 2015 yılı sonunda 280 milyon dolara yükselmiştir. İhracatın en önemli bitkileri kekik, haşhaş, defne, çay, anason, kimyon, adaçayı, mahlep, kırmızıbiber ve bitkisel çaylardır (ıhlamur, kuşburnu, adaçayı, karışık meyveler, vb.). İhracatta kekik \%25'lik payla ilk sıradadır. Kekik ihracatı, geçmişe oranla \%300 artışla 56 milyon dolara ulaşmış olup yaklaşık yarısı Ege Serbest Bölgesi'nden gerçekleştirilmektedir. Birçok bitkinin ihracatı artmışken buna karşın kırmızıbiber, kenevir, biberiye, nane, boya bitkilerinin ihracatinda azalma gözlenmiştir. İthalatın ise 2002 yılında 85 milyon dolardan \%370 artışla 400 milyon dolara ulaşmıştır. Kahve hariç ithalat 2002 yllında 72 milyon dolarken \%250 artışla 2015 yılı sonunda 254 milyon dolar olmuştur. İthalatın en önemli bitkileri kahve, çay, keten, karabiber, keçiboynuzu, kimyon, çörekotu, şerbetçiotu şeklindedir. İthalatın \%61'ini kahve oluşturmaktadır. Ayrıca kekik, defne, kimyon, kahve, adaçayı ve keçiboynuzu gibi birçok bitkide reeksport yapılmaktadır. Tıbbi ve aromatik bitkilerin, genellikle ham halde ihraç edilmekte olduğu görülmektedir. Katma değerli ürünlere dönşüm sağlanarak sektörden daha fazla ihracat getirisi sağlamak mümkündür.

Bitkisel ilaç hammaddesine ve ilaca gitmek istenilen ihracat hedefine ulaşmanin en güçlü yoludur. Günümüzde Türk ilaç sanayinin gerçek anlamda ilaç üreticisi olması ve referans ilaç üretmesi çok zor gözükmektedir. Ancak bitkisel ürünler ve bitkisel ilaçlar için durum böyle değildir. Bitkisel ürünlerin ve gıda takviyelerinin üretimi hızla artmaktadır ve artık ilaca ulaşma çabalarınında başarılı örnekleri de görülebilmektedir.

Dahilde işleme çerçevesinde bazı tıbbi ve aromatik bitkilerin ithali ve işlendikten sonra ihracatı tıbbi bitki ticaretinin önemli bir yeri vardır. Tıbbi bitkilerin ihracatı ham drog değil işlenerek yükte hafif pahada ağır ürünler haline getirilmelidir. Bu kapsamda katma değeri yüksek uçucu yağlar ve ekstratların ihracatına ağırlık verilmelidir. Fakat ülkemizin tıbbi bitki işleme tesisleri istenilen sevide değildir ve hemen halledilebilecek bir konuda değildir. Sektörün lokomotif gücü olan tıbbi bitki işleme sanayinin desteklenmesi ve geliştirilmesi bir zorunluluktur.

\section{KAYNAKLAR}

Anonim 2005. Medicinal and Aromatic Plants Working Group-ECP/GR.

Anonim 2012. Batı Akdeniz Kalkınma Ajansı Sektör Raporu, Antalya.

Anonim 2013. Antalya İli Tibbi Aromatik Bitkiler Florası. Antalya Ticaret Borsası.

Anonim 2016. Odun Dışı Orman Ürünlerinin Envanter ve Planlaması ile Üretim ve Satış Esasları, Tebliğ No: 302, Orman ve Su İşleri Bakanlığı Orman Genel Müdürlüğü Odun Dışı Ürün ve Hizmetler Dairesi Başkanlığı, Ankara.

Anonymous 2016. http://www.plant-medicine.com /uploads/whitleymapreport.pdf (t.y). 
Arslan N, Baydar H, Kızıl S, Karik Ü, Şekeroğlu N, Gümüş̧̧ü A 2015. Tıbbi ve Aromatik Bitkiler Üretiminde Değişimler ve Yeni Arayışlar. TMMOB Ziraat Mühendisliği VIII. Teknik Kongresi,12-16 Ocak, Bildiriler Kitabı-I, Sayfa 483-505, Ankara.

Başer KHC 1997. Tıbbi ve Aromatik Bitkilerin İlaç ve Alkollü İçki Sanayilerinde Kullanımı. İstanbul Ticaret Odası Yayın No: 1997-39, İstanbul.

Başer KHC 1998. Tıbbi ve Aromatik Bitkilerin Endüstriyel Kullanımı. Tıbbi ve Aromatik Bitkiler Bülteni, Sayı:13-14, Anadolu Üniversitesi Tibbi ve Aromatik Bitki ve İlaç Araştırma Merkezi, Eskişehir.

Başer KHC 2000. Uçucu Yağların Parlak Geleceği. Anadolu Üniversitesi Tibbi ve Aromatik Bitki ve İlaç Araştırma Merkezi, Tıbbi ve Aromatik Bitkiler Bülteni, Sayı:15, Eskişehir.

Bayram E, Kırıcı S, Tansı S, Yılmaz G, Arabacı O, Kızıl S, Telci I 2010. Tibbi ve Aromatik Bitkiler Üretiminin Artırılması Olanakları. Ziraat Mühendisliği VII. Teknik Kongresi, 11-15 Ocak, Ankara.

Ceylan A 1995. Tibbi Bitkiler I. Ege Üniversitesi Ziraat Fakültesi Yayınları No:312, III. Baskı, İzmir.

FAO, 2015. Corparate Document Repository. Impact of Cultivation and Gathering of Medicinal Plants on Biodiversity http://www.fao.org/docrep/005/aa010e/ aa010e02.htm. (Erişim Tarihi: 11.11.2015)

FAO 2017. Food and Agriculture Organization of the United Nations http://www.fao.org, (Erişim Tarihi:27.02.2017)

Faydaoğlu E, Sürücüoğlu MS 2011. Geçmişten Günümüze Tıbbi ve Aromatik Bitkilerin
Kullanılması ve Ekonomik Önemi. Kastamonu Üniversitesi Orman Fakültesi Dergisi 11(1):52-62.

ITC 2016. International Trade Statictics Database http://www.trademap.org/, (Erişim Tarihi: 18.03.2016)

Kartal M, Erdem SA 2012. Bitkisel Ürünlerde Dünya pazarı ve Türkiye. MíSED, Türk Eczacıları Birliği Meslek İçi Sürekli Eğitim Dergisi, 27-28:41-42

OGM 2016. Odun Dışı Orman Ürünlerinin Envanter ve Planlaması ile Üretim ve Satış Esasları, Tebliğ No: 302, https://www.ogm.gov.tr/ekutuphane/ Tebligler/.pdf. (Erişim Tarihi: 17.08. 2016)

Öztürk M, Temel M, Tinmaz AB 2016. Türkiye'de Defne Yaprağı Üretimi ve Pazarlaması. III. Tıbbi ve Aromatik Bitkiler Sempozyumu, 4-6 Ekim 2016, Antalya.

Suzer O 2005. Suzer Farmakoloji. 3. Baskı, Klinisyen Tip Kitabevleri, İstanbul, s. 533.

Temel M, Tınmaz AB, Öztürk M, Yoldaş N 2014. Tıbbi ve Aromatik Bitkiler Dünyasının Farklılaşmış Ürünü Şerbetçiotu. II. Tıbbi ve Aromatik Bitkileri Sempozyumu, 23-25 Eylül 2014, Yalova.

TÜİK 2016a. Türkiye İstatistik Kurumu. http://www.tuik.gov.tr/, (Erişim Tarihi:13.03.2016)

TÜİK 2016b. Türkiye İstatistik Kurumu Dış Ticaret Kayıtları, İstanbul Bölge Müdürlüğü.

Yıldırım H. T., 2011. Türkiye'nin Odun Dışı Orman Ürünleri Üretiminin Ormancılık Politikası Açısından Değerlendirilmesi. I. Ulusal Akdeniz Orman ve Çevre Sempozyumu, 26-28 Ekim 2011, Kahramanmaraş. 